Check for updates

Cite this: RSC Adv., 2018, 8, 37606

Received 21st August 2018

Accepted 18th October 2018

DOI: 10.1039/c8ra07013j

rsc.li/rsc-advances

\title{
L-Proline catalyzed one-pot synthesis of polysubstituted pyridine system incorporating benzothiazole moiety via sustainable sonochemical approach $\dagger$
}

\author{
Hamada Mohamed Ibrahim, (D) *a Wael Abdelgayed Ahmed Arafa (D) ab \\ and Haider Behbehani*c
}

\begin{abstract}
The efficient, highly convenient synthesis of polysubstituted pyridine derivatives was established via the reaction of $\mathrm{N}$-(benzothiazol-2-yl)-2-cyanoacetamides with an assortment of arylidene malononitriles and arylidene ethyl cyanoacetates in the presence of L-proline as an efficient organocatalyst for this type of ultrasonic-mediated Michael addition. The mechanistic pathway and factors affecting this reaction were also established. The main characteristics of this procedure are high yields, use of a cost-effective catalyst, and easy work-up and purification.
\end{abstract}

\section{Introduction}

Over the last few decades heterocyclic compounds have presented tremendous opportunities in the field of therapeutics and drug design. Many of these compounds play an important role in human life, plants and animals and have now been identified in all aspects of life. Among the heterocyclic compounds, the interesting aza-heterocycles are very important in medicinal chemistry. The presence of nitrogen may modulate the electron distribution inside heterocycles, leading to the modification of both the chemical and physical characteristics of these compounds, which also leads to modification in their biological properties and metabolic pathways. ${ }^{1}$ One of the most remarkable nitrogen-containing heterocycles is pyridine and its outstanding derivatives since it is the basic moiety in many natural products such as alkaloids. ${ }^{2,3}$ Moreover, pyridine-containing heterocycles have various biological and pharmacological activities, such as anti-microbial, ${ }^{4-6}$ anti-viral, ${ }^{7,8}$ antioxidant, ${ }^{9}$ anti-diabetic, ${ }^{10}$ anti-cancer and anti-tumor, ${ }^{11-14}$ anti-malarial, ${ }^{15,16}$ antiinflammatory, ${ }^{17,18}$ and anti-amoebic activities. ${ }^{19}$ In addition,

${ }^{a}$ Chemistry Department, Faculty of Science, Fayoum University, P. O. Box 63514, Fayoum, Egypt. E-mail: hmioo@fayoum.edu.eg; hamadaaldeb@yahoo.com; Fax: +965-248-164-82; Tel: +965-55216585

${ }^{b}$ Chemistry Department, College of Science, Jouf University, P. O. Box 2014, Sakaka, Aljouf, Kingdom of Saudi Arabia

${ }^{c}$ Chemistry Department, Faculty of Science, Kuwait University, P. O. Box 5969, Safat 13060, Kuwait. E-mail: drhaider.b@gmail.com; Fax: +965-248-164-82; Tel: +96555888646

$\dagger$ Electronic supplementary information (ESI) available. CCDC 1858431-1858434. For ESI and crystallographic data in CIF or other electronic format see DOI: 10.1039/c8ra07013j some pyridine-containing compounds exhibit analgesic potency ${ }^{\mathbf{2 0}}$ and enzyme inhibition. ${ }^{21}$ Furthermore, pyridine ring systems are used in medicine for the treatment of iron overload disease via the chelation effect of these compounds. ${ }^{22}$ Additionally, benzothiazole is one of the most significant heterocycles, which is the core structure of many pharmaceuticals and natural products. ${ }^{23-25}$ Recently, the concept of organocatalysis and sonochemical reactions has significantly grown as a result of both the juvenility of the concept and, more importantly, the selectivity and effectiveness of many organocatalytic reactions. Moreover, the sonication process has more inherent advantages compared to conventional heating, such as higher yields, moderate reaction conditions, shorter reaction times and easier workup. $^{26-28}$

Consequently, due to the above intriguing characteristics and applications, pyridines and fused pyridine derivatives are notable structures, which have attracted the interest of synthetic organic chemists. ${ }^{29,30}$ However, although numerous protocols have been developed in the last decade for the synthesis of multisubstituted pyridine derivatives, ${ }^{31-33}$ the development of highly efficient, convenient methods for the synthesis of polysubstituted pyridines is still a major demand in modern synthetic chemistry. Recently, in our laboratory we directed our effort to the development of efficient protocols for the synthesis of pyridine and fused pyridine derivatives. ${ }^{34-37}$ As a continuation of our research towards developing these protocols utilizing green methodologies, ${ }^{\mathbf{3 8 - 4 1}}$ herein, we report an efficient, eco-friendly strategy for the synthesis of polysubstituted pyridine derivatives utilizing L-proline as an ecofriendly organocatalyst, which is mediated by ultrasonic irradiation as an efficacious green energy source. ${ }^{\mathbf{4 2 , 4 3}}$ 


\section{Results and discussion}

The synthetic strategy of our research to obtain the targeted compounds commenced by preparing benzothiazole cyanoacetamide derivatives $\mathbf{4 a}$ and $\mathbf{b}$, which were prepared by the treatment of the 2-amino-benzothiazole derivatives $\mathbf{3 a}$ and b with a preheated mixture of cyanoacetic acid (1) in acetic anhydride under sonication (Scheme 1).

The formed benzothiazole cyanoacetamide derivatives $4 a$ and $\mathbf{b}$ represent valuable precursors to be tested for the synthesis of polyfunctional substituted pyridine derivatives. Thus, the active methylene moiety in the $N$-(benzothiazol-2-yl)2-cyanoacetamide derivatives $\mathbf{4 a}$ and $\mathbf{b}$ has high capability to undergo nucleophilic addition reaction with a variety of electrophilic reagents, such as arylidene malononitriles $\mathbf{5 a}-\mathbf{h}$ via a Michael-type addition reaction. ${ }^{\mathbf{4 4 - 4 6}}$ Thus, in this context of our study, which aimed to establish the best reaction conditions for the synthesis of pyridine derivatives via a green methodology, the reaction between $N$-(benzothiazol-2-yl)-2-cyanoacetamide (4a) and 2-benzylidenemalononitrile (5a) was tested in the presence of different types of organocatalysts as a model reaction. Firstly, we applied piperidine as catalyst to conduct the cycloaddition reaction between $N$-(benzothiazol-2-yl)-2cyanoacetamide (4a) (5 mmol) and 2-benzylidenemalononitrile $(5 \mathrm{a})(5 \mathrm{mmol})$ in ethanol $(20 \mathrm{~mL})$ under both conventional heating and ultrasonic irradiation to study the effect of the type of energy source, and the results are listed in Table 1. The structure of the obtained product was assigned as 6-amino-1benzothiazol-2-yl-2-oxo-4-phenyl-1,2-dihydro-pyridine-3,5dicarbonitrile (7a) based on the data obtained from several analysis tools, such as ${ }^{1} \mathrm{H}$ NMR, ${ }^{13} \mathrm{C}$ NMR, and mass and accurate mass determination. Moreover, this structure was also confirmed by the X-ray single crystal structure determination (Fig. 1 and Scheme 2). It is worth mentioning that the pyridine derivative $7 \mathbf{a}$ was obtained earlier by Stetinova et $a .^{47}$ through a comparable route via the reaction of 3-aryl- $\mathrm{N}-(2-$ benzothiazolyl)-2-cyano-2-propenamides (6) with malononitrile in ethanolic solution containing piperidine. However, the main disadvantage of their route is the low yield of the obtained pyridine derivative $\mathbf{7 a}$ in comparison with our synthetic
Table 1 Optimization of the conditions for the synthesis of $7 a^{a}$

\begin{tabular}{llllrl}
\hline Entry $^{a}$ & Catalyst & Solvent & Method & Time (min) & Yield (\%) \\
\hline 1 & Piperidine & EtOH & Heating & 120 & 59 \\
2 & Piperidine & EtOH & US ))) & 20 & 85 \\
3 & Morpholine & EtOH & Heating & 120 & 43 \\
4 & Morpholine & EtOH & US ))) & 20 & 77 \\
5 & L-Proline & EtOH & Heating & 120 & 74 \\
6 & L-Proline & EtOH & US ))) & 20 & 95 \\
7 & DBU & EtOH & Heating & 120 & 30 \\
8 & DBU & EtOH & US ))) & 20 & 45 \\
9 & DABCO & EtOH & Heating & 120 & 41 \\
10 & DABCO & EtOH & US ))) & 20 & 52 \\
11 & Imidazole & EtOH & Heating & 120 & 35 \\
12 & Imidazole & EtOH & US ))) & 25 & 56 \\
13 & L-Proline & $\mathrm{H}_{2} \mathrm{O}$ & Heating & 120 & $\mathrm{NR}^{b}$ \\
14 & L-Proline & $\mathrm{H}_{2} \mathrm{O}$ & US ))) & 60 & $\mathrm{NR}^{b}$
\end{tabular}

${ }^{a}$ Reaction conditions: $N$-(benzothiazol-2-yl)-2-cyanoacetamide (4a) (5 $\mathrm{mmol}), 2$-benzylidenemalononitrile $(5 \mathbf{5})(5 \mathrm{mmol})$, in solvent $(20 \mathrm{~mL})$ and catalyst $(10 \mathrm{~mol} \%)$ (in case of US, the temperature was $80{ }^{\circ} \mathrm{C}$ at $110 \mathrm{~W}) .{ }^{b}$ NR: no reaction.

procedure, even with the use of piperidine as the catalyst (Scheme 2). As shown in Table 1 (entries 1 and 2), the use of ultrasonic irradiation as the mode of activation for our reaction incredibly increased the reaction yield from 59\% (which was obtained using only thermal heating) to $85 \%$. Also, as noted, the reaction time was remarkably minimized from 2 hours (using conventional heating) to 20 minutes (using ultrasonic irradiation). From the results depicted in Table 1, we observed that this cycloaddition reaction could be effectively catalyzed by L-proline Table 1 (entry 6), while piperidine, morpholine, DBU, DBACO, and imidazole are less effective organocatalysts since they afforded lower yields. This may be attributed to the zwitterionic characteristic of L-proline, which makes it act as a bifunctional catalyst, in addition to the $\mathrm{H}$-bonding of proline in the enamine transition state playing an essential role in the reaction outcome. Furthermore, an enhancement was observed for both the reaction rate and yield when the above-mentioned reaction was conducted under ultrasonic irradiation (at $80^{\circ} \mathrm{C}, 110 \mathrm{~W}$ ). The use of ultrasound irradiation in chemical reactions in

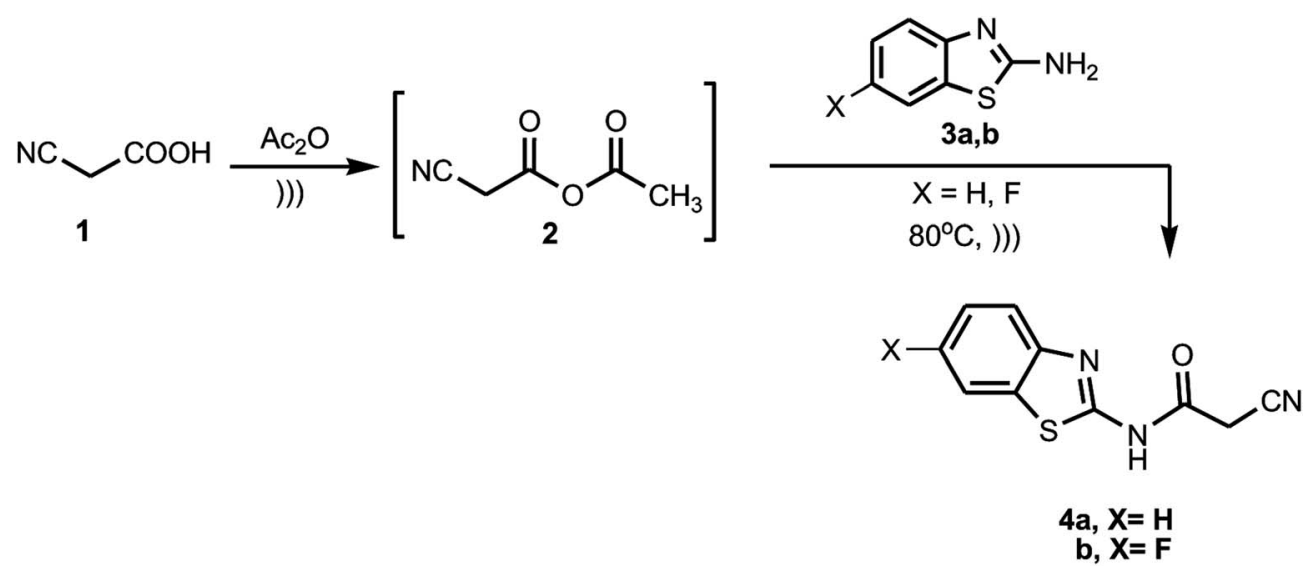

Scheme 1 Synthesis of benzothiazole cyanoacetamide derivatives $4 a$ and $b$. 


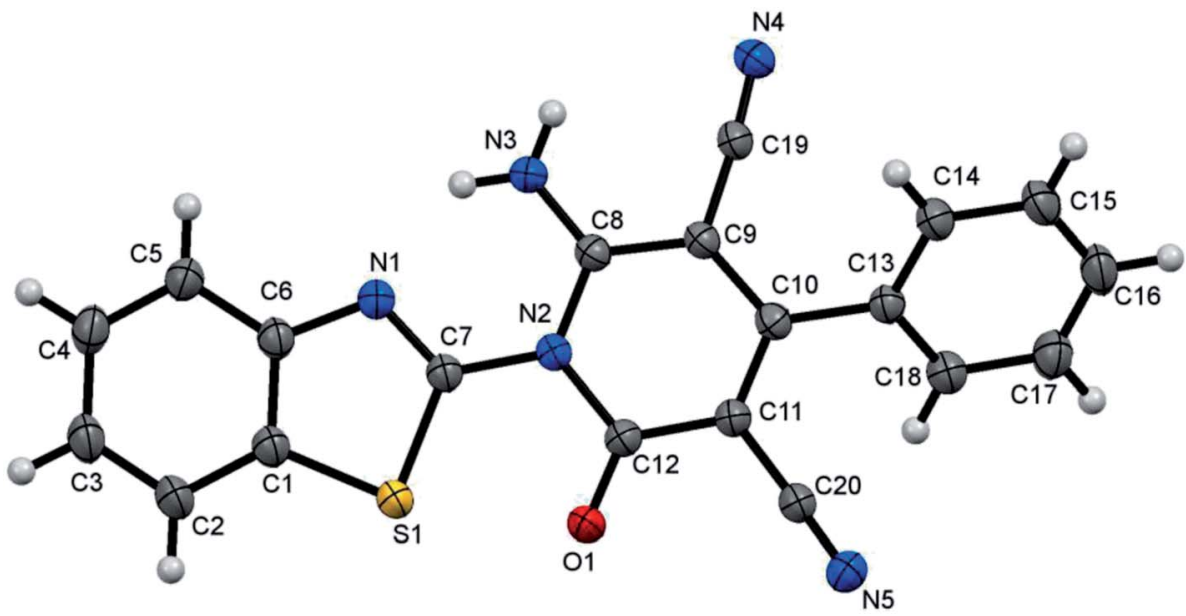

Fig. 1 X-ray single crystal structure determined for compound 7a.

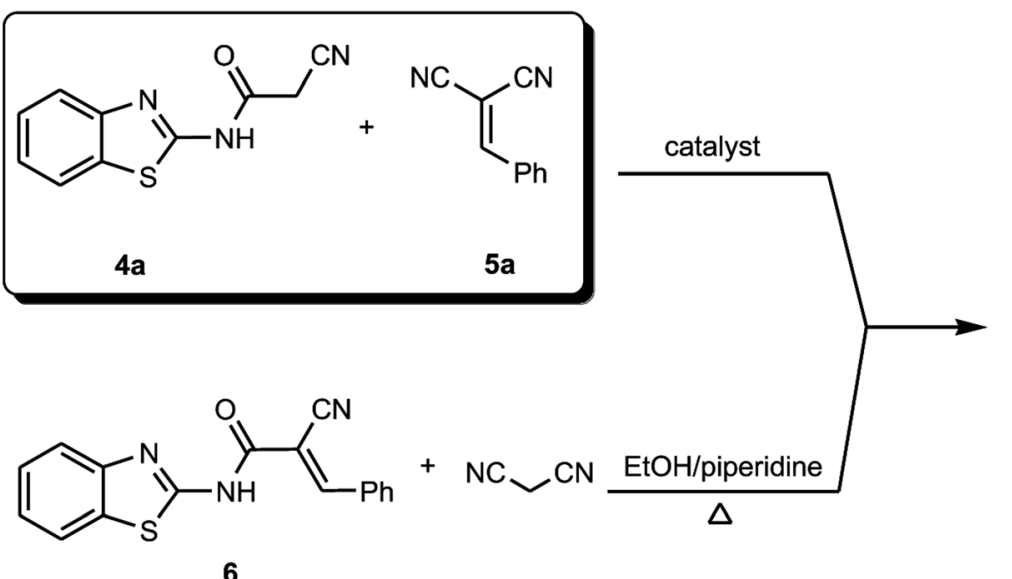<smiles>N#Cc1c(-c2ccccc2)c(C#N)c(=O)n(-c2nc3ccccc3s2)c1N</smiles>

7 a $(\text { yield } 34 \%)^{47}$

Scheme 2 Synthesis of benzothiazol-2-yl-pyridine derivative 7a.

solution, as an alternative energy source, has many advantages, including dramatic improvements in both stoichiometric and catalytic chemical reactions. In some cases, ultrasonic irradiation can increase the reactivity and the reaction rate by nearly a hundred-fold, which proceeds by the generation, growth, and collapse of acoustic bubbles in the reaction mixture. Accordingly, this assists in decreasing the reaction time and significantly enhancing the reaction yield. Then, we tried to use water as a green energy solvent to conduct the above reaction; however, we were unsuccessful mostly because most organic compounds do not dissolve adequately in water, as shown in Table 1 (entries 13 and 14). ${ }^{48}$ Alternatively, ethanol performed well as the reaction medium since it is a comparatively nonhazardous solvent to the environment, as shown in Table 1 (entry 6). ${ }^{49}$

Then, to estimate the influence of catalyst loading on this procedure, the model reaction (Scheme 2) was conducted by applying different amounts of $\mathrm{L}$-proline. The results depicted in Table 2 confirmed that $10 \mathrm{~mol} \%$ L-proline is the preferable molar ratio, which afforded the coveted product in excellent yield of $95 \%$, Table 2 (entry 6 ). When the molar ratio of L-proline was increased more than $10 \mathrm{~mol} \%$, the yield diminished, Table 2 (entries 1-5). Moreover, when the loading of the catalyst molar ratio was less than $10 \mathrm{~mol} \%$, the desired product was obtained in a slightly lower yield than that with $10 \mathrm{~mol} \%$ of L-proline, Table 2 (entries 7 and 8).

Table 2 Optimization mol\% of L-proline for the synthesis of $7 a^{a}$

\begin{tabular}{lccc}
\hline Entry $^{a}$ & $\begin{array}{l}\text { mol\% } \\
\text { of L-proline }\end{array}$ & Method & Yield (\%) \\
\hline 1 & 100 & US ))) & 27 \\
2 & 50 & US ))) & 38 \\
3 & 30 & US ))) & 53 \\
4 & 20 & US ))) & 69 \\
5 & 15 & US ))) & 82 \\
6 & 10 & US ))) & 95 \\
7 & 5 & US ))) & 93 \\
8 & 2 & US ))) & 88
\end{tabular}

${ }^{a}$ The mixture of $N$-(benzothiazol-2-yl)-2-cyanoacetamide (4a) $(5 \mathrm{mmol})$ and 2-benzylidenemalononitrile $(5 a)(5 \mathrm{mmol})$, in ethanol $(20 \mathrm{~mL})$ and L-proline was sonicated at $80{ }^{\circ} \mathrm{C}, 110 \mathrm{~W}$. 
<smiles>[X]c1ccc2nc(NC(=O)CC#N)sc2c1</smiles>

4a, $X=H$
NC<smiles>CC(C#N)=CBr</smiles>

5a-h<smiles>[X]c1ccc2nc(-n3c(N)c(C#N)c(Br)c(C#N)c3=O)sc2c1</smiles>

Scheme 3 Synthesis of 6-amino-1-benzothiazol-2-yl-2-oxo-4-arylpyridine-3,5-dicarbonitrile derivatives 7a-i.

Table 3 The reactions of $N$-(benzothiazol-2-yl)-2-cyanoacetamide derivatives 4 with arylidenemalononitriles $5^{a}$

\begin{tabular}{|c|c|c|c|c|c|}
\hline Entry & Products & $\mathrm{X}$ & $\mathrm{Ar}$ & Yield (\%)-mp $\left({ }^{\circ} \mathrm{C}\right)$ & $\begin{array}{l}\text { Reported yield } \\
(\%)-m p\left({ }^{\circ} \mathrm{C}\right)\end{array}$ \\
\hline 1 & $7 a$ & $\mathrm{H}$ & $\mathrm{C}_{6} \mathrm{H}_{5}$ & $95 / 300-302$ & $34 / 299-302$ \\
\hline 3 & $7 \mathrm{c}$ & $\mathrm{H}$ & $4-\mathrm{MeO}-\mathrm{C}_{6} \mathrm{H}_{4}$ & 92/above 300 & $17 / 308-311$ \\
\hline 4 & $7 d$ & $\mathrm{H}$ & $4-\mathrm{Cl}-\mathrm{C}_{6} \mathrm{H}_{4}$ & $87 /$ above 300 & $25 / 315-317$ \\
\hline 5 & $7 e$ & $\mathrm{H}$ & $4-\mathrm{NO}_{2}-\mathrm{C}_{6} \mathrm{H}_{4}$ & 90/above 300 & $32 / 306-309$ \\
\hline 8 & $7 \mathrm{~h}$ & $\mathrm{H}$ & $\mathrm{C}_{4} \mathrm{H}_{3} \mathrm{~S}$ & 90/above 300 & - \\
\hline 9 & $7 \mathbf{i}$ & $\mathrm{F}$ & $4-\mathrm{Cl}-\mathrm{C}_{6} \mathrm{H}_{4}$ & 94/above 300 & - \\
\hline
\end{tabular}

${ }^{a}$ Reaction conditions: the mixture of $N$-(benzothiazol-2-yl)-2-cyanoacetamide derivatives 4 (5 mmol) and arylidenemalononitriles 5 (5 mmol) in ethanol $(20 \mathrm{~mL})$ and $\mathrm{L}$-proline $(10 \mathrm{~mol} \%)$ was sonicated at $80^{\circ} \mathrm{C}, 110 \mathrm{~W}$ for $20 \mathrm{~min}$.

With the optimized green methodology in hand, we investigated the scope of this method for the synthesis of the benzothiazol-2-yl-pyridine derivatives 7a-i. This methodology was found to be applicable for the synthesis of a wide range of pyridone derivatives 7a-i through the reaction of $\mathrm{N}$ (benzothiazol-2-yl)-2-cyanoacetamide (4a) and 2-cyano- $N$-(6fluorobenzothiazol-2-yl)acetamide (4b) with an assortment of arylidenemalononitriles $\mathbf{5 a}-\mathbf{h}$ in ethanol containing $10 \mathrm{~mol} \%$ of
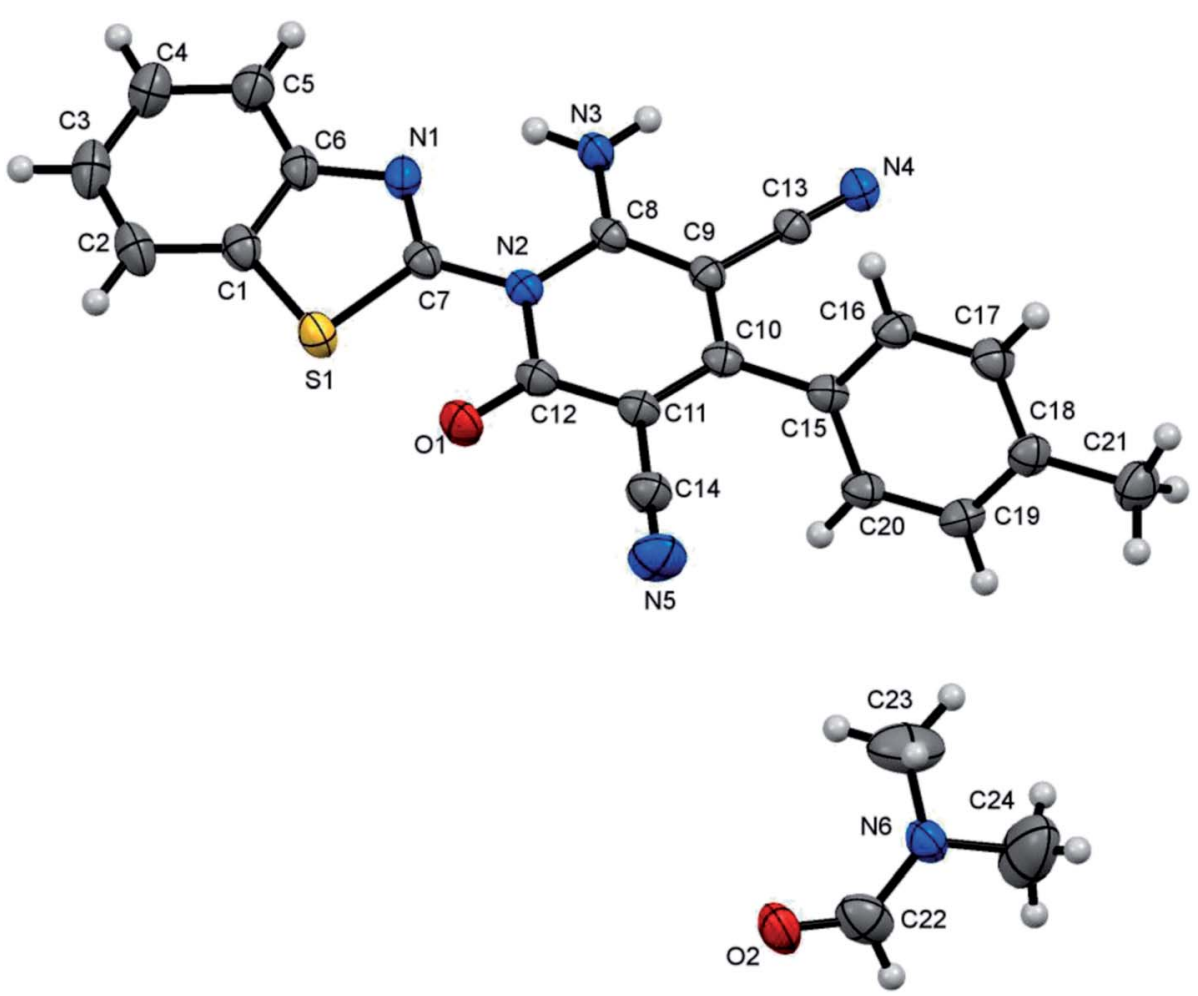

Fig. 2 X-ray single crystal structure determined for compound $7 \mathrm{~b}$. 


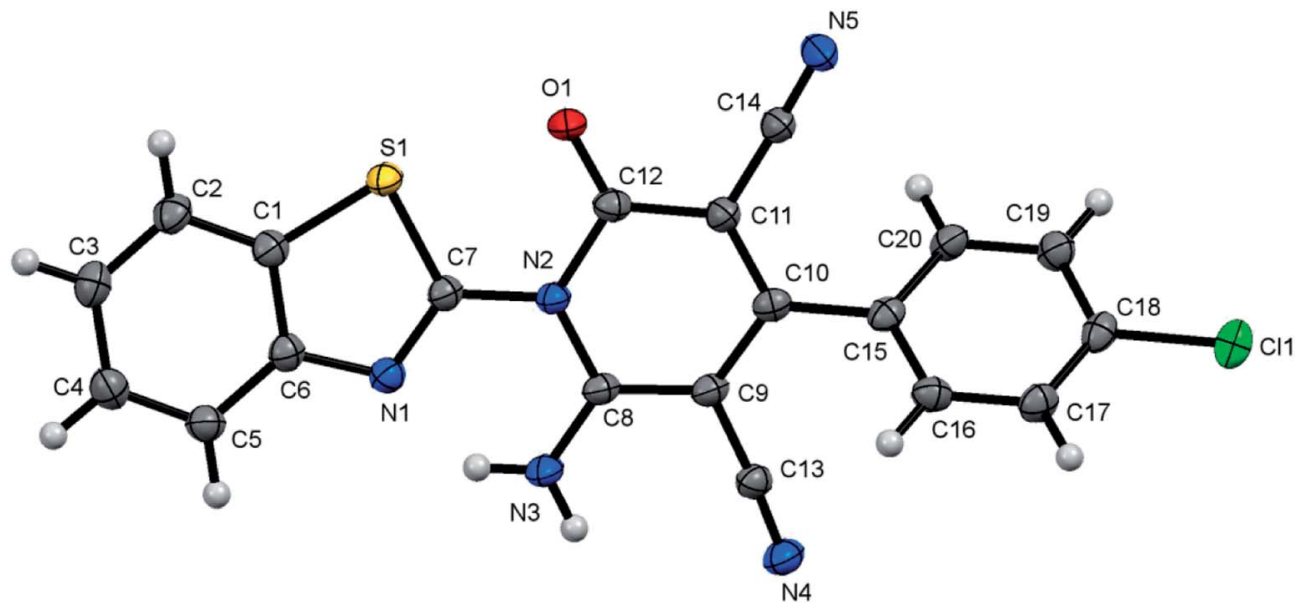

Fig. 3 X-ray single crystal structure determined for compound 7d.

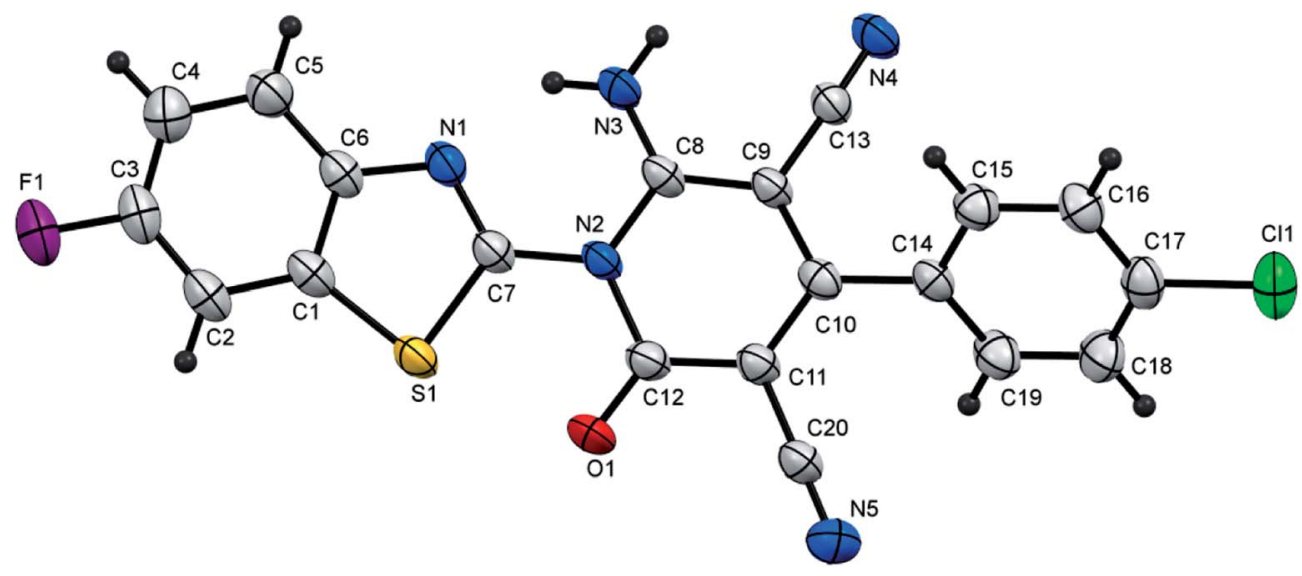

Fig. 4 X-ray single crystal structure determined for compound $7 \mathrm{i}$.<smiles>N#CCC(=O)Nc1nc2ccccc2s1</smiles>

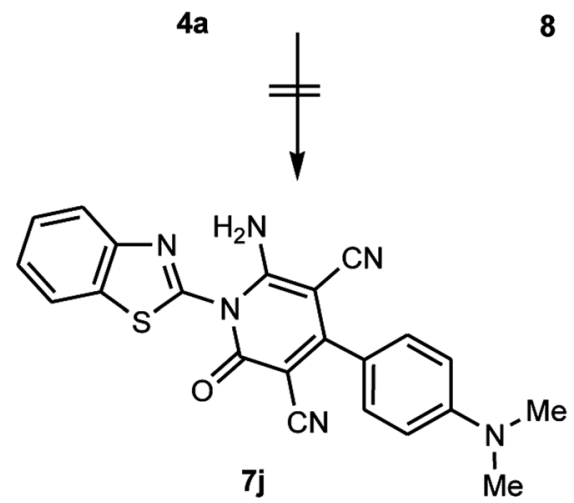<smiles>CN(C)c1ccc(C(CC(C)(C#N)C(C#N)C(=O)Nc2nc3ccccc3s2)C(C)(C)C)cc1</smiles>

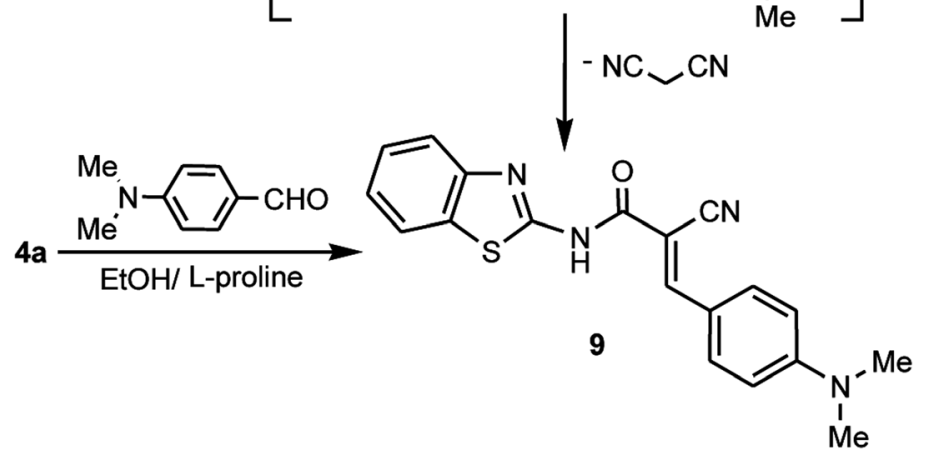

Scheme 4 Reaction of 4a with 2-(4-dimethylaminobenzylidene)malononitrile 8. 


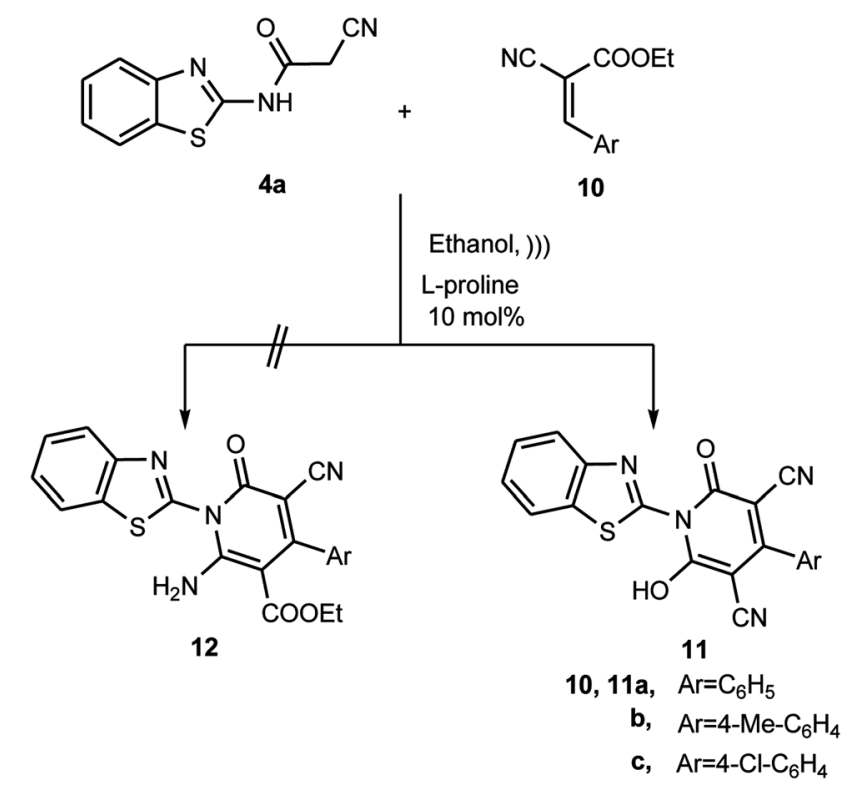

Scheme 5 Reaction of $4 a$ with ethyl-2-cyano-3-arylacrylates $10 a-c$.
L-proline under ultrasonic irradiation. It afforded the corresponding 6-amino-1-benzothiazol-2-yl-2-oxo-4-arylpyridine-3,5dicarbonitrile derivatives $7 \mathbf{a}-\mathbf{i}$ in excellent yields, as summarized in Scheme 3 and Table 3. In a similar manner to that used to characterize $\mathbf{7 a}$, the structures of $\mathbf{7 b} \mathbf{b}-\mathbf{i}$ were also determined from their full spectral data, which included ${ }^{1} \mathrm{H}$ and ${ }^{13} \mathrm{C}$ NMR spectra, IR, MS and HRMS and representative examples by X-ray crystallographic analysis for compounds $\mathbf{7 b}, \mathbf{7} \mathbf{d}$ and $\mathbf{7 i}$, as depicted in Fig. 2-4.

In contrast to the previously noted chemistry, the benzothiazolylcyanoacetamide derivative 4 a was reacted with 2-(4dimethylaminobenzylidene)malononitrile $\mathbf{8}$ to afford the arylidene derivative $\mathbf{9}$ and not the corresponding pyridone derivative $7 \mathbf{j}$. This may be attributed to the presence of a para-dimethylamino substituent in the aromatic moiety of the aldehyde, which is a donor-aromatic-acceptor structure. This facilitates the elimination of the malononitrile moiety rather than the cycloaddition of the $\mathrm{NH}$ moiety at $\mathrm{CN}$, which is consistent with an earlier study. ${ }^{44}$ The arylidene derivative $\mathbf{9}$ could also be obtained through the condensation reaction between the cyanoacetamide derivative $4 \mathbf{a}$ and 4-dimethylaminobenzaldehyde in EtOH/ L-proline (Scheme 4).

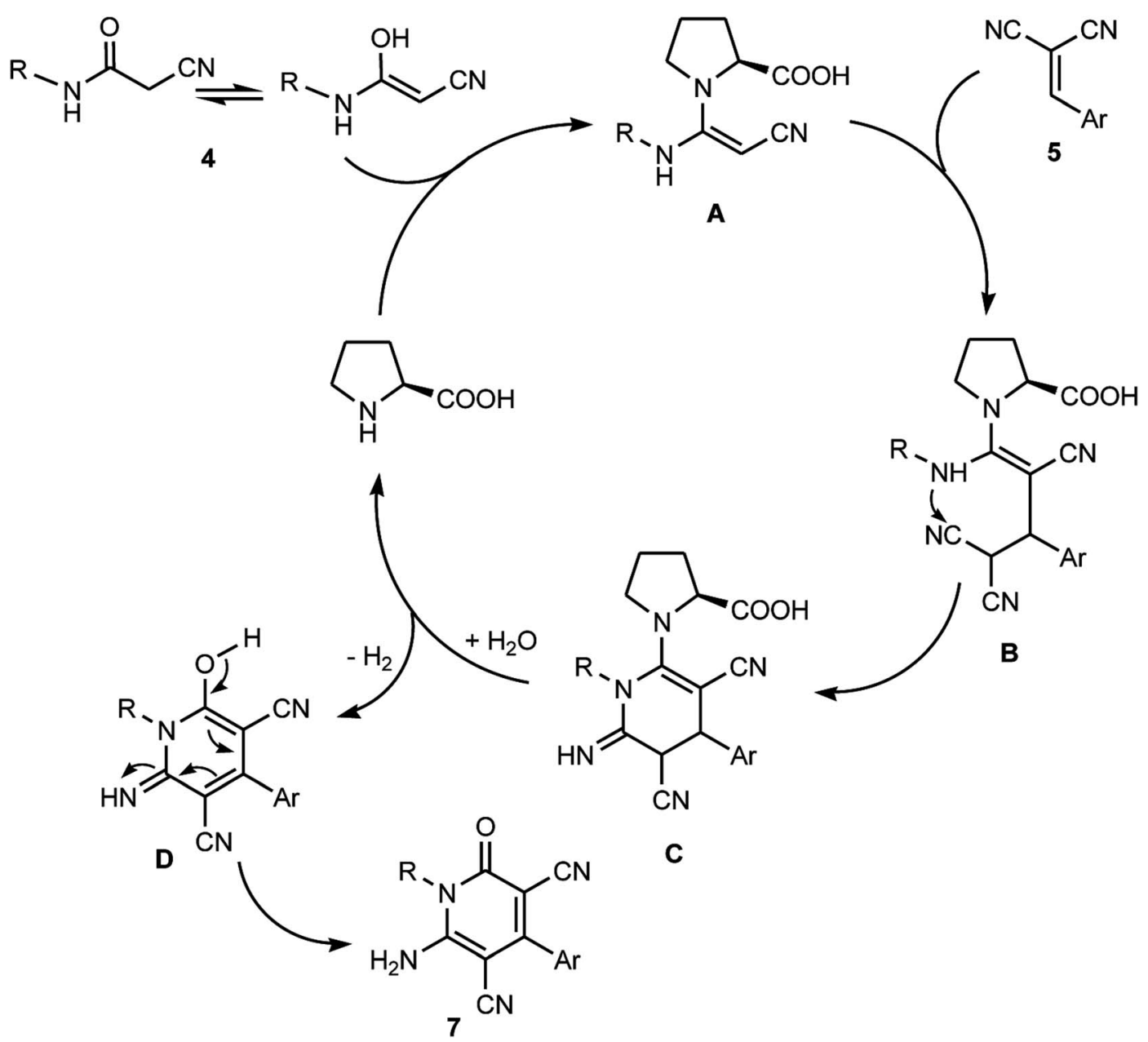

Scheme 6 Plausible mechanistic pathway for the formation of polysubstituted pyridone derivatives 7. 
Furthermore, to expand and generalize this L-proline catalyzed Michael-type addition reaction, we investigated the reaction of the $\mathrm{N}$-(benzothiazol-2-yl)-2-cyanoacetamide (4a) and ethyl-2-cyano-3-arylacrylate derivatives 10a-c. The sonication of $\mathrm{N}$-(benzothiazol-2-yl)-2-cyanoacetamide (4a) with ethyl-2cyano-3-arylacrylate derivatives $\mathbf{1 0 a - c}$ in ethanolic solution containing L-proline afforded the product, where structure $\mathbf{1 1}$ was assigned and not $\mathbf{1 2}$ based on the different spectrometric analyses (Scheme 5). For example, the ${ }^{1} \mathrm{H}$ NMR spectrum of the reaction product was devoid of the triplet and quartet signal set, which is due to the ethyl ester. Also, it revealed sets of multiplets in the region $\delta \approx 7.4-8.7 \mathrm{ppm}$ due to the aromatic protons signals besides the singlet signal at $\delta \approx 13.3 \mathrm{ppm}$, which is due the hydroxyl group proton. In addition, all the data obtained from the IR, MS, HRMS and ${ }^{13} \mathrm{C}$ NMR spectra are consistent with the hydroxypyridone structure 11.

Remarkably, various factors make this Michael addition protocol for the synthesis of multisubstituted pyridone derivatives highly appealing. These include the uncommonly high efficiency of the reaction, which was manifested in the excellent yield of the reaction product in comparison with the reported procedure for the assembly of 7 , the employment of ultrasonic irradiation as a clean, sustainable energy source, simple workup procedure and moderate reaction conditions. The plausible mechanistic pathway for the formation of the multisubstituted pyridone derivatives 7 is presented in Scheme 6. It is believed that the enamine adduct $\mathbf{A}$ was firstly formed between the cyanoacetamide $\mathbf{4}$ and L-proline, then the last intermediate underwent nucleophilic addition to 2-arylidenemalononitriles $\mathbf{5 a}-\mathbf{h}$ to generate the non-isolable intermediate $\mathbf{B}$, which underwent intramolecular cyclization via the attack of the $\mathrm{NH}$ moiety at $\mathrm{CN}$ to form the pyridine-imine intermediate $\mathbf{C}$. In the presence of water and by losing one hydrogen molecule, the intermediate D was liberated, which eventually rearranged to afford the corresponding pyridone derivatives 7 (Scheme 6).

Furthermore, the cyanoacetamide 4a was reacted with the enaminone $\mathbf{1 3}$ in a buffered solution of acetic acid containing anhydrous sodium acetate under ultrasonic irradiation to afford a product whose structure was assigned as pyridone $\mathbf{1 7}$ based on the obtained results from different spectrometric analyses. For example, the ${ }^{1} \mathrm{H}$ NMR spectrum exhibited two $\mathrm{NH}$ signals due to the amide $\mathrm{NH}$ and the pyridone $\mathrm{NH}$ at $\delta \approx 13.22$ and $13.59 \mathrm{ppm}$, respectively, in addition to two doublets at $\delta \approx 6.96$ and $8.54 \mathrm{ppm}$ for the two adjacent $\mathrm{C}-\mathrm{H}$ protons in the pyridone ring, plus sets of multiplets in the region $\delta \approx 7.96-8.55 \mathrm{ppm}$, which are due to the aromatic proton signals. Also, MS and HRMS showed the exact molecular weight corresponding the pyridone structure 17. Moreover, the data obtained from the ${ }^{13} \mathrm{C}$ NMR spectra clarify the presence of two signals due to $2 \mathrm{C}=\mathrm{O}$ groups. Thus, we postulate that cyanoacetamide $\mathbf{4 a}$ underwent nucleophilic addition to the enaminone $\mathbf{1 3}$ to give the non-isolable adduct 14, which by elimination of the dimethylamine moiety afforded the intermediate 15, which underwent intramolecular cyclization via the attack of the $\mathrm{OH}$ moiety at $\mathrm{CN}$ to form the pyrane-imine intermediate 16, and eventually rearranged to afford the corresponding pyridone derivative $\mathbf{1 7}$ (Scheme 7).

Finally, with the aim to evaluate the scalability of the $\mathrm{L}^{-}$ proline catalyzed research protocol reported in this study, we

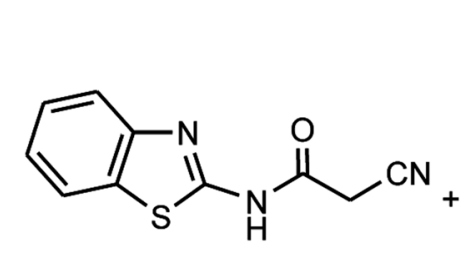

$4 a$

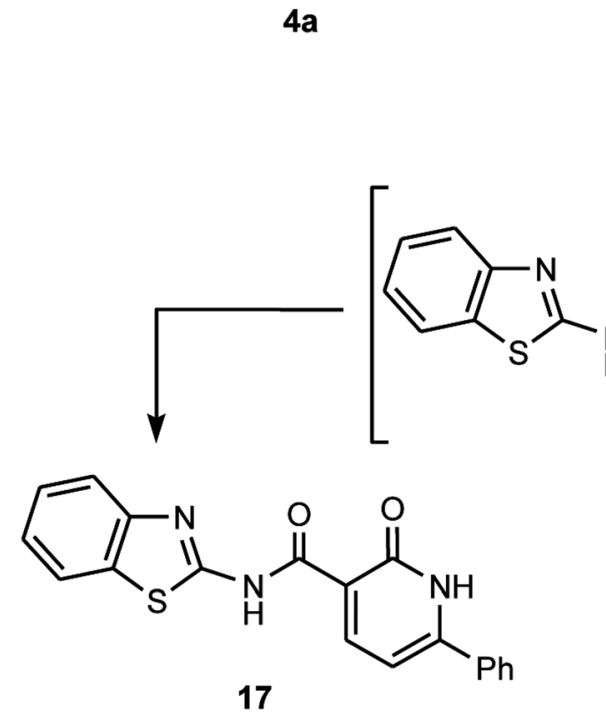

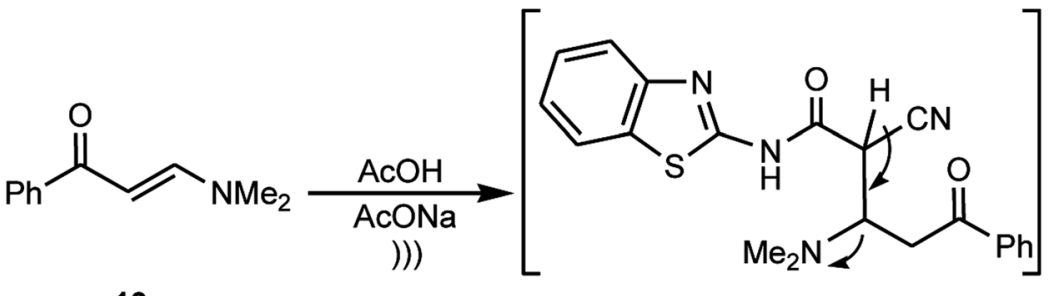

13

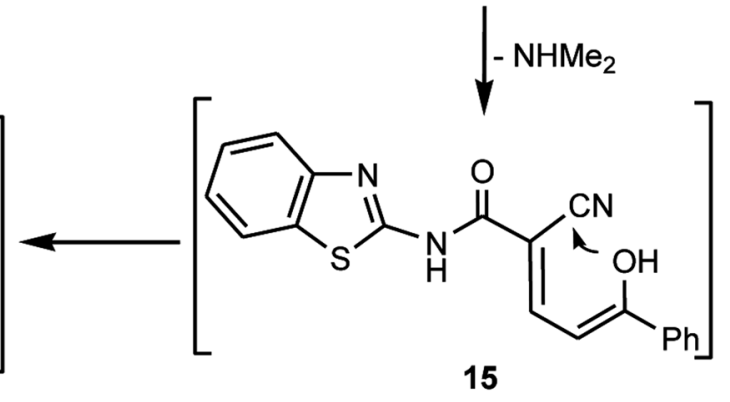

Scheme 7 Reaction of cyanoacetamide 4a with the enaminone 13. 


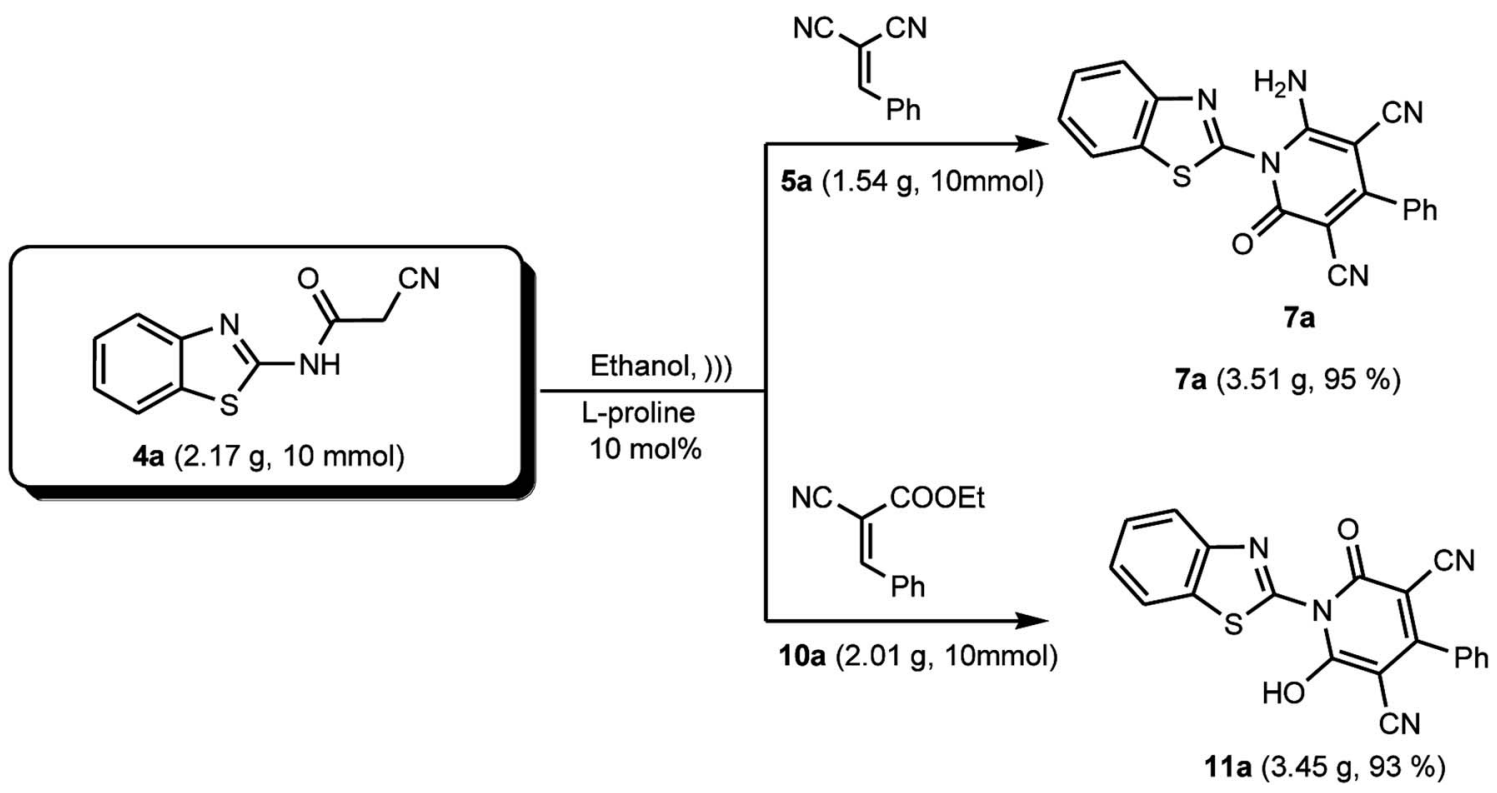

Scheme 8 Scaled-up synthesis of compounds 7a and 11a.

conducted this reaction on a gram-scale under the optimized reaction conditions, which furnished the desired products $7 \mathrm{a}$ and 11a, as representative examples, in excellent yields of 95\% and 93\%, respectively (Scheme 8).

\section{Conclusion}

In the present research, L-proline was successfully employed as an environmentally precious organocatalyst for the synthesis of a variety of polysubstituted pyridone systems incorporating the benzothiazole moiety. In combination with the use of ultrasonic irradiation as a sustainable energy source for conducting, this synthesis makes it valuable in comparison with the traditional methods. The current protocol has several unrivaled merits including excellent yields of reactions that may significantly participate in the commercialization of drugs. In addition, it utilizes a cost-effective catalyst and has easy work-up and purification. Also, in terms of efficiency, the use of ultrasonic irradiation for this process proved to be superior.

\section{Experimental}

\section{General}

Melting points were recorded on a Griffin melting point apparatus and are uncorrected. IR spectra were recorded using $\mathrm{KBr}$ disks on a Jasco FT-IR-6300 spectrophotometer. ${ }^{1} \mathrm{H}$ NMR (400 $\mathrm{MHz}$ or $600 \mathrm{MHz})$ and ${ }^{13} \mathrm{C}$ NMR $(100 \mathrm{MHz}$ or $150 \mathrm{MHz})$ spectra were recorded at $25{ }^{\circ} \mathrm{C}$ using DMSO- $d_{6}$ as the solvent with TMS as the internal standard on a Bruker DPX 400 or 600 superconducting NMR spectrometer. Chemical shifts are reported in ppm. Low-resolution electron impact mass spectra [MS (EI)] and high-resolution electron impact mass spectra [HRMS (EI)] were obtained using a high resolution GC-MS (DFS) thermo spectrometer at $70.1 \mathrm{eV}$ and a magnetic sector mass analyzer.
The reactions were followed and the homogeneity of the prepared compounds verified using thin layer chromatography (TLC). X-ray crystal structures were determined using a Rigaku R-AXIS RAPID diffractometer and Bruker X8 Prospector, and the collection of single crystal data was done at room temperature using $\mathrm{Cu}-\mathrm{K} \alpha$ radiation. The structures were solved using direct methods and expanded using Fourier techniques. Nonhydrogen atoms were refined anisotropically. The structures were solved and refined using the Bruker SHELXTL software package (structure solution program - SHELXS-97 and refinement program - SHELXL-97).50 Data were corrected for absorption effects using the multi-scan method (SADABS). Sonication was performed in an MKC6, Guyson ultrasonic bath (Model-MKC6, operating frequency $38 \mathrm{kHz} \pm 10 \%$ and an output power of $110 \mathrm{~W}$ ) with a digital timer ( $6 \mathrm{~s}$ to $100 \mathrm{~min}$ ) and heater, which allowed the solution to be heated from $20{ }^{\circ} \mathrm{C}$ to $80{ }^{\circ} \mathrm{C}$ in $1{ }^{\circ} \mathrm{C}$ increments. The inner tank dimensions were 150 $\times 300 \times 150 \mathrm{~mm}$ (length $\times$ width $\times$ depth) with a fluid capacity of $6 \mathrm{~L}$. The $N$-(benzothiazol-2-yl)-2-cyanoacetamide derivatives $4 \mathbf{a}$ and $\mathbf{b}$ were prepared according to a literature procedure with slight modification. ${ }^{51}$

\section{General procedure for the preparation of the cyanoacetamide} derivatives $4 a$ and $b$

A solution of cyanoacetic acid (1) $(10 \mathrm{mmol})$ in $\mathrm{Ac}_{2} \mathrm{O}(10 \mathrm{~mL})$ was sonicated in an MKC6, Guyson ultrasonic bath (Model-MKC6, operating frequency $38 \mathrm{kHz} \pm 10 \%$ and output power of 110 W) for about 1 min until the cyanoacetic acid was completely dissolved. Then, the appropriate 2 -aminobenzothiazole derivatives $3 \mathbf{a}$ and $\mathbf{b}(10 \mathrm{mmol})$ were added to the reaction mixture, and sonication was continued for a further $5 \mathrm{~min}$ at $80^{\circ} \mathrm{C}$. The reaction mixture was left to cool to room temperature. The solid product formed was collected by filtration and recrystallized 
from the appropriate solvent and identified as (4a and $\mathbf{b}$, respectively).

$\boldsymbol{N}$-(Benzothiazol-2-yl)-2-cyanoacetamide (4a). ${ }^{51}$ Recrystallized from EtOH/dioxane mixture $(1: 1)$ as creamy white crystals, yield: $2.15 \mathrm{~g}$ (99\%), $\mathrm{mp} 220-221{ }^{\circ} \mathrm{C}$; IR (KBr): $3288(\mathrm{NH}), 2261$ (CN), $1688 \mathrm{~cm}^{-1}$ (CO); ${ }^{1} \mathrm{H}$ NMR (DMSO- $\left.d_{6}\right): \delta=4.14\left(\mathrm{~s}, 2 \mathrm{H}, \mathrm{CH}_{2}\right.$ ), 7.29-8.01 (m, 4H, Ar-H) and $12.74(\mathrm{br}, 1 \mathrm{H}, \mathrm{NH}) ;{ }^{13} \mathrm{C}$ NMR $\left(\mathrm{DMSO}-d_{6}\right): \delta=27.3\left(\mathrm{CH}_{2}\right), 116.0(\mathrm{CN}), 121.5,122.6,124.7$, 127.1, 132.3, 149.1, 158.4 (Ar-C) and 163.8 (CO); MS (EI): $m / z(\%)$ $217\left(\mathrm{M}^{+}, 31.93\right), 218\left(\mathrm{M}^{+}+1,4.6\right)$. HRMS (EI): $\mathrm{m} / z$ calcd for $\mathrm{C}_{10} \mathrm{H}_{7} \mathrm{~N}_{3} \mathrm{OS}\left(\mathrm{M}^{+}\right)$217.0304, found 217.0304.

2-Cyano- $\boldsymbol{N}$-(6-fluorobenzothiazol-2-yl)acetamide (4b). Recrystallized from EtOH/dioxane mixture $(1: 1)$ as yellowish white crystals, yield: $2.3 \mathrm{~g}$ (98\%), mp 193-194 ${ }^{\circ} \mathrm{C}$; IR (KBr): $3305(\mathrm{NH})$, 2258 (CN), $1685 \mathrm{~cm}^{-1}$ (CO); ${ }^{1} \mathrm{H}$ NMR (DMSO- $\left.d_{6}\right): \delta=4.12(\mathrm{~s}, 2 \mathrm{H}$, $\mathrm{CH}_{2}$ ), 7.28-7.94 (m, 3H, Ar-H) and 12.65 (brs, $\left.1 \mathrm{H}, \mathrm{NH}\right) ;{ }^{13} \mathrm{C}$ NMR $\left(\right.$ DMSO- $\left.d_{6}\right): \delta=26.38\left(C_{2}\right), 108.17,108.35\left(\mathrm{~d},{ }^{2} J_{\mathrm{CF}}=27 \mathrm{~Hz}\right)$, 114.34, $114.50\left(\mathrm{~d},{ }^{2} J_{\mathrm{CF}}=24 \mathrm{~Hz}\right) 115.14(\mathrm{CN}), 121.87,121.94(\mathrm{~d}$, $\left.{ }^{3} J_{\mathrm{CF}}=10.5 \mathrm{~Hz}\right), 132.76,132.83\left(\mathrm{~d},{ }^{3} J_{\mathrm{CF}}=10.5 \mathrm{~Hz}\right), 145.12$, 157.56, 158.08, 159.68 (Ar-C) and 162.99 (CO); MS (EI): $m / z(\%)$ $235\left(\mathrm{M}^{+}, 64.99\right), 236\left(\mathrm{M}^{+}+1,7.94\right)$. HRMS (EI): $\mathrm{m} / z$ calcd for $\mathrm{C}_{10} \mathrm{H}_{6 \mathrm{FN}} \mathrm{OS}\left(\mathrm{M}^{+}\right)$235.0210, found 235.0210.

General procedure for the preparation of 6-amino-1-(benzothiazol2-yl)-2-oxo-4-arylpyridine-3,5-dicarbonitrile derivatives $7 \mathbf{a}-\mathbf{i}$

Mixtures of cyanoacetamide derivatives $4 \mathbf{a}$ and $\mathbf{b}(5 \mathrm{mmol})$, arylidene malononitrile $5 \mathbf{a}-\mathbf{h}(5 \mathrm{mmol})$ and L-proline $(0.5 \mathrm{mmol}$, $10 \mathrm{~mol} \%)$ in ethanol $(20 \mathrm{~mL})$ were sonicated in an MKC6, Guyson ultrasonic bath (Model-MKC6, operating frequency 38 $\mathrm{kHz} \pm 10 \%$ and output power of $110 \mathrm{~W}$ ) for 20 minutes at $80{ }^{\circ} \mathrm{C}$. The reaction was followed by TLC and continued until the starting substrates were completely consumed, then left to cool to room temperature. In each case, the solid product formed after cooling to room temperature was separated by filtration, washed with ethanol, dried and recrystallized from the appropriate solvent to give the pure products $7 \mathbf{a}-\mathbf{i}$.

6-Amino-1-(benzothiazol-2-yl)-2-oxo-4-phenyl-1,2-dihydropyridine-3,5-dicarbonitrile(7a). ${ }^{47}$ Creamy white crystals, yield: $1.75 \mathrm{~g}$ (95\%), mp 300-302 ${ }^{\circ} \mathrm{C}$; IR (KBr): $\nu / \mathrm{cm}^{-1} 3321$ $\left(\mathrm{NH}_{2}\right), 2210(\mathrm{CN}), 1677$ (CO); ${ }^{1} \mathrm{H}$ NMR (DMSO- $\left.d_{6}\right): \delta=7.59-$ $7.65(\mathrm{~m}, 7 \mathrm{H}, \mathrm{Ar}-\mathrm{H}), 8.12(\mathrm{~d}, J=8.4 \mathrm{~Hz}, 1 \mathrm{H}, \mathrm{Ar}-\mathrm{H}), 8.22(\mathrm{~d}, J=$ $8.4 \mathrm{~Hz}, 1 \mathrm{H}, \mathrm{Ar}-\mathrm{H})$ and $8.71 \mathrm{ppm}\left(\mathrm{s}, 2 \mathrm{H}, \mathrm{NH}_{2}\right) ;{ }^{13} \mathrm{C} \mathrm{NMR}$ (DMSO- $d_{6}$ ): $\delta=75.84$ (C5), 87.68 (C3), 114.53, 114.96, 122.10, 123.23, 125.97, 126.10, 127.39, 128.20, 129.99, 134.21, 136.34, 149.12, 154.09, 156.50, 158.67 and $162.03 \mathrm{ppm}(\mathrm{Ar}-\mathrm{C}$ and CO); MS (EI): $m / z(\%) 370\left(\mathrm{M}^{+}+1,26.84\right), 369\left(\mathrm{M}^{+}, 100\right)$; HRMS (EI): $m / z$ calcd for $\mathrm{C}_{20} \mathrm{H}_{11} \mathrm{~N}_{5} \mathrm{OS}\left(\mathrm{M}^{+}\right) 369.0679$, found 369.0679. Crystal data, moiety formula: $\mathrm{C}_{20} \mathrm{H}_{11} \mathrm{~N}_{5} \mathrm{OS}, M=$ 369.40, triclinic, $a=6.43370(10) \AA, b=11.1793(3) \AA, c=$

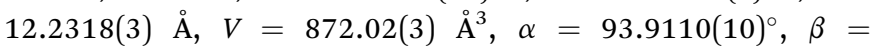
94.6660 $(10)^{\circ}, \gamma=94.2320(10)^{\circ}$, space group: $P \overline{1}, Z=2, D_{\text {calc }}=$ $1.407 \mathrm{~g} \mathrm{~cm}^{-3}$, no. of reflection measured $=14792, \theta_{\max }=$ $66.44^{\circ}, R 1=0.0347$ (CCDC 1858431). ${ }^{52}$

6-Amino-1-(benzothiazol-2-yl)-2-oxo-4-p-tolyl-1,2-dihydropyridine3,5-dicarbonitrile (7b). ${ }^{47}$ Creamy white crystals, yield: $1.74 \mathrm{~g}$ (91\%), mp 300-301 ${ }^{\circ} \mathrm{C}$; IR (KBr): $\nu / \mathrm{cm}^{-1} 3319\left(\mathrm{NH}_{2}\right), 2224,2211$ (CN), 1674
(CO); ${ }^{1} \mathrm{H}$ NMR (DMSO- $\left.d_{6}\right): \delta=2.42\left(\mathrm{~s}, 3 \mathrm{H}, \mathrm{CH}_{3}\right), 7.42-7.63(\mathrm{~m}, 6 \mathrm{H}$, $\mathrm{Ar}-\mathrm{H}), 8.13$ (d, J = 7.2 Hz, 1H, Ar-H), 8.25 (d, $J=7.2 \mathrm{~Hz}, 1 \mathrm{H}, \mathrm{Ar}-\mathrm{H})$ and $8.76 \mathrm{ppm}\left(\mathrm{s}, 2 \mathrm{H}, \mathrm{NH}_{2}\right) ;{ }^{13} \mathrm{C}$ NMR (DMSO- $\left.d_{6}\right): \delta=20.99\left(\mathrm{CH}_{3}\right)$, 75.83 (C5), 87.51 (C3), 115.37, 115.94, 122.83, 123.69, 126.27, 126.42, 127.88, 129.22, 131.54, 137.35, 140.43, 149.98, 154.29, 156.88, 159.33 and $162.51 \mathrm{ppm}$ (Ar-C and CO); MS (EI): $m / z(\%) 384\left(\mathrm{M}^{+}+1,25.97\right)$, $383\left(\mathrm{M}^{+}, 100\right)$; HRMS (EI): $m / z$ calcd for $\mathrm{C}_{21} \mathrm{H}_{13} \mathrm{~N}_{5} \mathrm{OS}\left(\mathrm{M}^{+}\right)$383.0835, found 383.0835. Crystal data, moiety formula: $\mathrm{C}_{21} \mathrm{H}_{13} \mathrm{~N}_{5} \mathrm{OS}, M=$ 383.43, sum formula: $\mathrm{C}_{24} \mathrm{H}_{20} \mathrm{~N}_{6} \mathrm{O}_{2} \mathrm{~S}, M=456.52$, triclinic, $a=$ 9.3107(2) $\mathrm{A}, b=10.8553(2) \AA, c=12.3036(3) \AA, V=1117.81(4) \AA^{3}$, $\alpha=71.3360(10)^{\circ}, \beta=71.5960(10)^{\circ}, \gamma=84.7560(10)^{\circ}$, space group: $P \overline{1}, Z=2, D_{\text {calc }}=1.356 \mathrm{~g} \mathrm{~cm}^{-3}$, no. of reflection measured $=13761$, $\theta_{\max }=66.66^{\circ}, R 1=0.0725\left(\right.$ CCDC 1858432).$^{53}$

6-Amino-1-(benzothiazol-2-yl)-4-(4-methoxyphenyl)-2-oxo-1,2dihydropyridine-3,5-dicarbonitrile (7c). ${ }^{47}$ Creamy white crystals, yield: $1.84 \mathrm{~g}$ (92\%), mp above $300{ }^{\circ} \mathrm{C}$; IR (KBr): $\nu / \mathrm{cm}^{-1} 3311\left(\mathrm{NH}_{2}\right)$, 2214 (CN), 1677 (CO); ${ }^{1} \mathrm{H}$ NMR (DMSO- $d_{6}$ ): $\delta=3.87$ (s, 3H, $\mathrm{OCH}_{3}$ ), $7.16(\mathrm{~d}, J=8.0 \mathrm{~Hz}, 2 \mathrm{H}, \mathrm{Ar}-\mathrm{H}), 7.56-7.65(\mathrm{~m}, 4 \mathrm{H}, \mathrm{Ar}-\mathrm{H}), 8.13$ (d, $J=$ $7.2 \mathrm{~Hz}, 1 \mathrm{H}, \mathrm{Ar}-\mathrm{H}), 8.25(\mathrm{~d}, J=7.2 \mathrm{~Hz}, 1 \mathrm{H}, \mathrm{Ar}-\mathrm{H})$ and $8.76 \mathrm{ppm}(\mathrm{s}$, $\left.2 \mathrm{H}, \mathrm{NH}_{2}\right) ;{ }^{13} \mathrm{C}$ NMR (DMSO- $\left.d_{6}\right): \delta=55.37\left(\mathrm{OCH}_{3}\right), 75.82$ (C5), 87.40 (C3), 114.03, 115.56, 116.14, 122.81, 123.69, 126.29, 126.44, 129.85, 137.32, 149.96, 154.33, 156.89, 159.41, 160.98 and 162.14 ppm (Ar$\mathrm{C}$ and CO); MS (EI): $m / z(\%) 400\left(\mathrm{M}^{+}+1,27.12\right), 399\left(\mathrm{M}^{+}, 100\right)$; HRMS (EI): $m / z$ calcd for $\mathrm{C}_{21} \mathrm{H}_{13} \mathrm{~N}_{5} \mathrm{O}_{2} \mathrm{~S}\left(\mathrm{M}^{+}\right)$399.0784, found 399.0784.

6-Amino-1-(benzothiazol-2-yl)-4-(4-chlorophenyl)-2-oxo1,2-dihydropyridine-3,5-dicarbonitrile (7d). ${ }^{47}$ Creamy white crystals, yield: $1.75 \mathrm{~g}$ (87\%), mp above $300{ }^{\circ} \mathrm{C}$; IR (KBr): $\nu /$ $\mathrm{cm}^{-1} 3329\left(\mathrm{NH}_{2}\right), 2224,2210(\mathrm{CN}), 1678$ (CO); ${ }^{1} \mathrm{H}$ NMR (DMSO- $\left.d_{6}\right): \delta=7.58-7.66(\mathrm{~m}, 4 \mathrm{H}, \mathrm{Ar}-\mathrm{H}), 7.70(\mathrm{~d}, J=7.6 \mathrm{~Hz}$, $2 \mathrm{H}, \mathrm{Ar}-\mathrm{H}), 8.13$ (d, $J=7.6 \mathrm{~Hz}, 1 \mathrm{H}, \mathrm{Ar}-\mathrm{H}), 8.26$ (d, $J=7.6 \mathrm{~Hz}$, $1 \mathrm{H}, \mathrm{Ar}-\mathrm{H})$ and $8.82 \mathrm{ppm}\left(\mathrm{s}, 2 \mathrm{H}, \mathrm{N} H_{2}\right) ;{ }^{13} \mathrm{C}$ NMR (DMSO- $\left.d_{6}\right)$ : $\delta=75.87$ (C5), 87.65 (C3), 115.14, 115.70, 122.86, 123.72, 126.30, 126.44, 128.91, 129.87, 133.31, 135.35, 137.36, 150.02, 154.14, 156.85, 159.17 and 161.33 ppm (Ar-C and CO); MS (EI): $m / z(\%) 405\left(\mathbf{M}^{+}+2,37.45\right), 404\left(\mathbf{M}^{+}+1,51.95\right), 403\left(\mathbf{M}^{+}\right.$, 100); HRMS (EI): $m / z$ calcd for $\mathrm{C}_{20} \mathrm{H}_{10} \mathrm{ClN}_{5} \mathrm{OS}\left(\mathrm{M}^{+}\right)$403.0289, found 403.0288. Crystal data, moiety formula: $\mathrm{C}_{20} \mathrm{H}_{10} \mathrm{ClN}_{5} \mathrm{OS}$, $M=403.84$, triclinic, $a=6.4441(8) \AA$, $b=12.311(2) \AA, c=$ 12.747(2) $\mathrm{A}, V=873.1(2) \AA^{3}, \alpha=61.344(5)^{\circ}, \beta=80.031(6)^{\circ}, \gamma$ $=83.005(6)^{\circ}$, space group: $P \overline{1}, Z=2, D_{\text {calc }}=1.536 \mathrm{~g} \mathrm{~cm}^{-3}$, no. of reflection measured $=8558, \theta_{\max }=54.9^{\circ}, R 1=0.0349$ (CCDC 1858433). ${ }^{54}$

6-Amino-1-(benzothiazol-2-yl)-4-(4-nitrophenyl)-2-oxo-1,2dihydropyridine-3,5-dicarbonitrile (7e). ${ }^{47}$ Yellow crystals, yield: $1.86 \mathrm{~g}$ (90\%), mp above $300{ }^{\circ} \mathrm{C}$; IR (KBr): $\nu / \mathrm{cm}^{-1} 3297$ $\left(\mathrm{NH}_{2}\right), 2216$ (CN), 1679 (CO); ${ }^{1} \mathrm{H}$ NMR (DMSO- $\left.d_{6}\right): \delta=7.59-7.67$ $(\mathrm{m}, 2 \mathrm{H}, \mathrm{Ar}-\mathrm{H}), 7.90(\mathrm{~d}, J=8.0 \mathrm{~Hz}, 2 \mathrm{H}, \mathrm{Ar}-\mathrm{H}), 8.14(\mathrm{~d}, J=7.6 \mathrm{~Hz}$, $1 \mathrm{H}, \mathrm{Ar}-\mathrm{H}), 8.26$ (d, $J=7.6 \mathrm{~Hz}, 1 \mathrm{H}, \mathrm{Ar}-\mathrm{H}), 8.47$ (d, $J=8.0 \mathrm{~Hz}$, $2 \mathrm{H}, \mathrm{Ar}-\mathrm{H}$ ) and $8.92 \mathrm{ppm}\left(\mathrm{s}, 2 \mathrm{H}, \mathrm{NH}_{2}\right) ;{ }^{13} \mathrm{C}$ NMR (DMSO- $\left.d_{6}\right): \delta=$ 75.83 (C5), 87.69 (C3), 115.00, 115.55, 122.97, 123.84, 124.10, 126.43, 126.56, 129.72, 137.46, 140.83, 148.67, 150.14, 154.11, 156.98, 159.14 and $160.61 \mathrm{ppm}$ (Ar-C and CO); MS (EI): $\mathrm{m} / z$ (\%) $415\left(\mathrm{M}^{+}+1,30.02\right), 414\left(\mathrm{M}^{+}, 100\right)$; HRMS (EI): $\mathrm{m} / z$ calcd for $\mathrm{C}_{20} \mathrm{H}_{10} \mathrm{~N}_{6} \mathrm{O}_{3} \mathrm{~S}\left(\mathrm{M}^{+}\right)$414.0530, found 414.0530.

6-Amino-1-(benzothiazol-2-yl)-4-(3-nitrophenyl)-2-oxo-1,2dihydropyridine-3,5-dicarbonitrile (7f). Pale yellow crystals, 
yield: $1.84 \mathrm{~g}$ (89\%), mp above $300{ }^{\circ} \mathrm{C}$; IR (KBr): $\nu / \mathrm{cm}^{-1} 3328$ $\left(\mathrm{NH}_{2}\right), 2209$ (CN), 1676 (CO); ${ }^{1} \mathrm{H}$ NMR (DMSO- $d_{6}$ ): $\delta=7.59-7.66$ $(\mathrm{m}, 2 \mathrm{H}, \mathrm{Ar}-\mathrm{H}), 7.94(\mathrm{t}, J=7.8 \mathrm{~Hz}, 1 \mathrm{H}, \mathrm{Ar}-\mathrm{H}), 8.06(\mathrm{~d}, J=7.8 \mathrm{~Hz}$, $1 \mathrm{H}, \mathrm{Ar}-\mathrm{H}), 8.13$ (d, $J=7.8 \mathrm{~Hz}, 1 \mathrm{H}, \mathrm{Ar}-\mathrm{H}), 8.24$ (d, $J=7.8 \mathrm{~Hz}, 1 \mathrm{H}$, $\mathrm{Ar}-\mathrm{H}), 8.45-8.48(\mathrm{~m}, 2 \mathrm{H}, \mathrm{Ar}-\mathrm{H})$, and $8.88 \mathrm{ppm}\left(\mathrm{s}, 2 \mathrm{H}, \mathrm{NH}_{2}\right) ;{ }^{13} \mathrm{C}$ NMR (DMSO- $d_{6}$ ): $\delta=76.01$ (C5), 87.82 (C3), 114.74, 115.24, 122.59, 122.73, 123.59, 124.99, 126.20, 126.32, 130.58, 134.37, $135.87,136.99,147.56,149.79,153.93,156.74,158.84$ and $159.89 \mathrm{ppm}$ (Ar-C and CO); MS (EI): $m / z(\%) 415\left(\mathrm{M}^{+}+1,27.34\right)$, $414\left(\mathrm{M}^{+}, 100\right)$; HRMS (EI): $m / z$ calcd for $\mathrm{C}_{20} \mathrm{H}_{10} \mathrm{~N}_{6} \mathrm{O}_{3} \mathrm{~S}\left(\mathrm{M}^{+}\right)$ 414.0530, found 414.0531.

6-Amino-1-(benzothiazol-2-yl)-4-(2,4-dimethoxyphenyl)2-oxo-1,2-dihydropyridine-3,5-dicarbonitrile (7g). Yellow crystals, yield: $2.05 \mathrm{~g}$ (96\%), mp above $300{ }^{\circ} \mathrm{C}$; IR (KBr): $\nu / \mathrm{cm}^{-1}$ $3308\left(\mathrm{NH}_{2}\right), 2216(\mathrm{CN}), 1675(\mathrm{CO}) ;{ }^{1} \mathrm{H}$ NMR (DMSO- $\left.d_{6}\right): \delta=3.89$ $\left(\mathrm{s}, 3 \mathrm{H}, \mathrm{OCH}_{3}\right), 3.92\left(\mathrm{~s}, 3 \mathrm{H}, \mathrm{OCH}_{3}\right), 6.71(\mathrm{~s}, 1 \mathrm{H}, \mathrm{Ar}-\mathrm{H}), 6.75(\mathrm{~d}, J$ $=8.4 \mathrm{~Hz}, 1 \mathrm{H}, \mathrm{Ar}-\mathrm{H}), 7.30(\mathrm{t}, J=7.8 \mathrm{~Hz}, 1 \mathrm{H}, \mathrm{Ar}-\mathrm{H}), 7.45(\mathrm{t}, J=$ $7.8 \mathrm{~Hz}, 1 \mathrm{H}, \mathrm{Ar}-\mathrm{H}), 8.04$ (d, $J=7.8 \mathrm{~Hz}, 1 \mathrm{H}, \mathrm{Ar}-\mathrm{H}), 8.20-8.25(\mathrm{~m}$, $2 \mathrm{H}, \mathrm{Ar}-\mathrm{H}$ ) and $8.78 \mathrm{ppm}\left(\mathrm{s}, 2 \mathrm{H}, \mathrm{NH}_{2}\right) ;{ }^{13} \mathrm{C}$ NMR (DMSO- $\left.d_{6}\right): \delta=$ 55.94, $56.31\left(2 \mathrm{OCH}_{3}\right), 75.80$ (C5), 87.34 (C3), 98.36, 107.70, $113.12,114.18,115.24,116.49,121.84,122.98,123.82,125.95$, $126.40,130.47,147.69,153.81,161.31,161.34,162.68$ and $165.87 \mathrm{ppm}$ (Ar-C and CO); MS (EI): $m / z(\%) 430\left(\mathrm{M}^{+}+1\right.$, 30.08), $429\left(\mathrm{M}^{+}, 100\right)$; HRMS (EI): $\mathrm{m} / z$ calcd for $\mathrm{C}_{22} \mathrm{H}_{15} \mathrm{~N}_{5} \mathrm{O}_{3} \mathrm{~S}$ $\left(\mathrm{M}^{+}\right)$429.0890, found 429.0891.

6-Amino-1-(benzothiazol-2-yl)-2-oxo-4-(thiophen-2-yl)1,2-dihydropyridine-3,5-dicarbonitrile (7h). Yellowish green crystals, yield: $1.68 \mathrm{~g}$ (90\%), mp above $300{ }^{\circ} \mathrm{C}$; IR (KBr): $\nu / \mathrm{cm}^{-1}$ $3307\left(\mathrm{NH}_{2}\right), 2213(\mathrm{CN}), 1671(\mathrm{CO}) ;{ }^{1} \mathrm{H}$ NMR (DMSO- $\left.d_{6}\right): \delta=$ 7.31-7.61 (m, 4H, Ar-H), 7.99 (d, J=4.4 Hz, 1H, Ar-H), 8.12 (d, $J=7.6 \mathrm{~Hz}, 1 \mathrm{H}, \mathrm{Ar}-\mathrm{H}), 8.24(\mathrm{~d}, J=7.6 \mathrm{~Hz}, 1 \mathrm{H}, \mathrm{Ar}-\mathrm{H})$ and $8.77 \mathrm{ppm}\left(\mathrm{s}, 2 \mathrm{H}, \mathrm{NH} \mathrm{H}_{2}\right) ;{ }^{13} \mathrm{C}$ NMR (DMSO- $\left.d_{6}\right): \delta=75.73$ (C5), 87.42 (C3), 115.48, 116.00, 122.83, 123.68, 126.27, 126.42, 127.82, 130.87, 131.20, 133.15, 137.35, 149.92, 154.20, 154.44, 156.97 and 159.27 ppm (Ar-C and CO); MS (EI): $\mathrm{m} / z$ (\%) 376 $\left(\mathrm{M}^{+}+1\right.$, 27.05), $375\left(\mathrm{M}^{+}, 100\right)$; HRMS (EI): $\mathrm{m} / \mathrm{z}$ calcd for $\mathrm{C}_{18} \mathrm{H}_{9} \mathrm{~N}_{5} \mathrm{OS}_{2}\left(\mathrm{M}^{+}\right)$375.0243, found 375.0242.

6-Amino-4-(4-chlorophenyl)-1-(6-fluorobenzothiazol-2-yl)2-oxo-1,2-dihydropyridine-3,5-dicarbonitrile (7i). Creamy white crystals, yield: $1.98 \mathrm{~g}(94 \%)$, mp above $300{ }^{\circ} \mathrm{C}$; IR $(\mathrm{KBr})$ : $\nu / \mathrm{cm}^{-1} 3317\left(\mathrm{NH}_{2}\right), 2225,2214(\mathrm{CN}), 1678(\mathrm{CO}) ;{ }^{1} \mathrm{H} \mathrm{NMR}$ $\left(\right.$ DMSO- $\left.d_{6}\right): \delta=7.51(\mathrm{~d}, J=8.8 \mathrm{~Hz}, 1 \mathrm{H}, \mathrm{Ar}-\mathrm{H}), 7.61(\mathrm{~d}, J=$ $8.0 \mathrm{~Hz}, 2 \mathrm{H}, \mathrm{Ar}-\mathrm{H}), 7.70$ (d, $J=8.0 \mathrm{~Hz}, 2 \mathrm{H}, \mathrm{Ar}-\mathrm{H}), 8.14-8.18(\mathrm{~m}$, $2 \mathrm{H}, \mathrm{Ar}-\mathrm{H}$ ) and $8.81 \mathrm{ppm}\left(\mathrm{s}, 2 \mathrm{H}, \mathrm{N} H_{2}\right) ;{ }^{13} \mathrm{C}$ NMR (DMSO- $\left.d_{6}\right)$ : $\delta=75.95$ (C5), 87.70 (C3), 109.04, 109.31 (d, $\left.{ }^{2} J_{\mathrm{CF}}=27 \mathrm{~Hz}\right)$, $115.11,115.36\left(\mathrm{~d},{ }^{2} J_{\mathrm{CF}}=25 \mathrm{~Hz}\right) 115.23,115.78,125.31,125.41$ $\left(\mathrm{d},{ }^{3} J_{\mathrm{CF}}=10.0 \mathrm{~Hz}\right), 129.00,129.94,133.37,135.45,138.73$, $138.84\left(\mathrm{~d},{ }^{3} J_{\mathrm{CF}}=11.0 \mathrm{~Hz}\right), 146.96,154.16,156.95,159.04$, 159.25 (Ar-C) and $161.42 \mathrm{ppm}$ (Ar-C and CO); MS (EI): $m / z$ (\%) $423\left(\mathrm{M}^{+}+2,38.12\right), 422\left(\mathrm{M}^{+}+1,56.89\right), 421\left(\mathrm{M}^{+}, 100\right)$; HRMS (EI): $m / z$ calcd for $\mathrm{C}_{20} \mathrm{H}_{9} \mathrm{ClFN}_{5} \mathrm{OS}\left(\mathrm{M}^{+}\right) 421.0195$, found 421.0196. Crystal data, moiety formula: $\mathrm{C}_{20} \mathrm{H}_{9} \mathrm{ClFN}_{5} \mathrm{OS}, M=$ 421.83, triclinic, $a=6.6752(3) \AA, b=11.0006(6) \AA, c=$ 13.2731(8) $\mathrm{\AA}, V=884.07(8) \AA^{3}, \alpha=67.007(3)^{\circ}, \beta=80.203(3)^{\circ}$, $\gamma=85.509(3)^{\circ}$, space group: $P \overline{1}, Z=2, D_{\text {calc }}=1.585 \mathrm{~g} \mathrm{~cm}^{-3}$, no. of reflection measured $=12731, \theta_{\max }=66.14^{\circ}, R 1=$ 0.0465 (CCDC 1858434)..$^{55}$
(E)-N-(Benzothiazol-2-yl)-2-cyano-3-[4-(dimethylamino)phenyl] acrylamide (9)

A mixture of the cyanoacetamide derivative $4 \mathbf{a}(5 \mathrm{mmol})$, arylidene malononitrile 8 ( $5 \mathrm{mmol})$ or 4 -(dimethylamino)benzaldehyde (5 mmol), and L-proline ( $0.5 \mathrm{mmol}, 10 \mathrm{~mol} \%)$ in ethanol (20 $\mathrm{mL}$ ) was sonicated in an MKC6, Guyson ultrasonic bath (ModelMKC6, operating frequency $38 \mathrm{kHz} \pm 10 \%$ and output power of $110 \mathrm{~W}$ ) for 20 minutes at $80{ }^{\circ} \mathrm{C}$. The reaction was monitored by TLC and continued until the starting substrates were completely consumed, then left to cool to room temperature. In each case, the solid product formed after cooling to room temperature was separated by filtration, washed with ethanol, dried and recrystallized from ethanol/dioxane mixture $(1: 1)$ to give 9 as the pure product. Orange crystals, yield: $1.69 \mathrm{~g}$ (97\%), mp above $300{ }^{\circ} \mathrm{C}$; IR (KBr): $\nu / \mathrm{cm}^{-1} 3400\left(\mathrm{NH}_{2}\right), 2198(\mathrm{CN}), 1679(\mathrm{CO}){ }^{1} \mathrm{H}$ NMR (DMSO$\left.d_{6}\right): \delta=3.07\left(\mathrm{~s}, 6 \mathrm{H}, 2 \mathrm{CH}_{3}\right), 6.84(\mathrm{~d}, J=8.4 \mathrm{~Hz}, 2 \mathrm{H}, \mathrm{Ar}-\mathrm{H}), 7.32(\mathrm{t}, J$ $=7.6 \mathrm{~Hz}, 1 \mathrm{H}, \mathrm{Ar}-\mathrm{H}), 7.46$ (t, $J=7.6 \mathrm{~Hz}, 1 \mathrm{H}, \mathrm{Ar}-\mathrm{H}), 7.65$ (d, $J=$ $7.6 \mathrm{~Hz}, 1 \mathrm{H}, \mathrm{Ar}-\mathrm{H}), 7.93-7.95$ (m, 3H, Ar-H), 8.30 (s, 1H, arylidene $\mathrm{C}-H$ ) and $12.94 \mathrm{ppm}(\mathrm{s}, 1 \mathrm{H}, \mathrm{N} H) ;{ }^{13} \mathrm{C}$ NMR (DMSO- $\left.d_{6}\right): \delta=40.64$ $\left(2 \mathrm{CH}_{3}\right)$ 98.23, 112.24, 118.16, 118.24, 119.40, 122.32, 124.11, $126.88,130.40,133.77,144.35,152.37,154.15,162.47$ and $166.20 \mathrm{ppm}$ (Ar-C and CO); MS (EI): $m / z(\%) 349\left(\mathrm{M}^{+}+1,9.05\right)$, $348\left(\mathrm{M}^{+}, 33\right)$; HRMS (EI): $m / z$ calcd for $\mathrm{C}_{19} \mathrm{H}_{16} \mathrm{~N}_{4} \mathrm{OS}\left(\mathrm{M}^{+}\right)$348.1039, found 348.1039.

General procedure for the preparation of 1-(benzothiazol-2-yl)6-hyroxy-2-oxo-4-arylpyridine-3,5-dicarbonitrile derivatives 11a-c

Mixtures of the cyanoacetamide derivative $4 \mathbf{4}(5 \mathrm{mmol})$, ethyl-2cyano-3-arylacrylate 10a-c $(5 \mathrm{mmol})$ and L-proline $(0.5 \mathrm{mmol}$, $10 \mathrm{~mol} \%)$ in ethanol $(20 \mathrm{~mL})$ were sonicated in an MKC6, Guyson ultrasonic bath (Model-MKC6, operating frequency 38 $\mathrm{kHz} \pm 10 \%$ and an output power of $110 \mathrm{~W}$ ) for 20 minutes at $80{ }^{\circ} \mathrm{C}$. The reaction was controlled by TLC and continued until the starting substrates were completely consumed, then left to cool to room temperature. In each case, the solid product formed after cooling to room temperature was separated by filtration, washed with ethanol, dried and recrystallized from ethanol to give 11a-c as pure products.

1-(Benzothiazol-2-yl)-6-hydroxy-2-oxo-4-phenyl-1,2-dihydropyridine3,5-dicarbonitrile (11a). Creamy white crystals, yield: $1.72 \mathrm{~g}$ (93\%), mp above $300{ }^{\circ} \mathrm{C}$; IR (KBr): $\nu / \mathrm{cm}^{-1} 3159(\mathrm{OH}), 2225(\mathrm{CN}), 1677$ (CO); ${ }^{1} \mathrm{H}$ NMR (DMSO- $d_{6}$ ): $\delta=7.36-7.38(\mathrm{~m}, 2 \mathrm{H}, \mathrm{Ar}-\mathrm{H}), 7.49-$ 7.55 (m, 5H, Ar-H), 8.07 (d, $J=8.4 \mathrm{~Hz}, 1 \mathrm{H}, \mathrm{Ar}-\mathrm{H}), 8.56$ (d, $J=$ $8.4 \mathrm{~Hz}, 1 \mathrm{H}, \mathrm{Ar}-\mathrm{H})$ and $13.23 \mathrm{ppm}(\mathrm{s}, 1 \mathrm{H}, \mathrm{OH}) ;{ }^{13} \mathrm{C}$ NMR (DMSO$\left.d_{6}\right): \delta=89.09$ (C5), 102.79 (C3), $115.17(\mathrm{CN}), 118.56,123.27$, 123.32, 126.97, 127.01, 127.44, 127.96, 128.63, 135.78, 136.54, 154.33, 156.56, 161.31 and 165.97 ppm (Ar-C and CO); MS (EI): $m / z(\%) 371\left(\mathbf{M}^{+}+1,28.12\right), 370\left(\mathbf{M}^{+}, 100\right)$; HRMS (EI): $m / z$ calcd for $\mathrm{C}_{20} \mathrm{H}_{10} \mathrm{~N}_{4} \mathrm{O}_{2} \mathrm{~S}\left(\mathrm{M}^{+}\right)$370.0519, found 370.0521 .

1-(Benzothiazol-2-yl)-6-hydroxy-2-oxo-4-p-tolyl-1,2-

dihydropyridine-3,5-dicarbonitrile (11b). Creamy white crystals, yield: $1.84 \mathrm{~g}$ (96\%), mp above $300{ }^{\circ} \mathrm{C}$; IR (KBr): $\nu / \mathrm{cm}^{-1} 3167$ $(\mathrm{OH}), 2223(\mathrm{CN}), 1672(\mathrm{CO}) ;{ }^{1} \mathrm{H}$ NMR $\left(\mathrm{DMSO}-d_{6}\right): \delta=2.44(\mathrm{~s}, 3 \mathrm{H}$, $\mathrm{CH}_{3}$ ), 7.27-7.31 (m, 4H, Ar-H), 7.49-7.54 (m, 2H, Ar-H), 8.01 (d, $J=7.8 \mathrm{~Hz}, 1 \mathrm{H}, \mathrm{Ar}-\mathrm{H}), 8.58(\mathrm{~d}, J=7.8 \mathrm{~Hz}, 1 \mathrm{H}, \mathrm{Ar}-\mathrm{H})$ and 
$12.80 \mathrm{ppm}(\mathrm{s}, 1 \mathrm{H}, \mathrm{OH}) ;{ }^{13} \mathrm{C}$ NMR $\left(\mathrm{DMSO}-d_{6}\right): \delta=20.60\left(\mathrm{CH}_{3}\right)$, 97.72 (C5), 102.78 (C3), 114.70 (CN), 118.29, 122.82, 123.01, 126.66, 126.74, 127.06, 128.15, 133.28, 135.48, 137.75, 153.94, 156.11, 159.48, 161.19 and $165.52 \mathrm{ppm}$ (Ar-C and CO); MS (EI): $m / z(\%) 385\left(\mathbf{M}^{+}+1,26.54\right), 384\left(\mathbf{M}^{+}, 100\right)$; HRMS (EI): $m / z$ calcd for $\mathrm{C}_{21} \mathrm{H}_{12} \mathrm{~N}_{4} \mathrm{O}_{2} \mathrm{~S}\left(\mathrm{M}^{+}\right)$384.0675, found 384.0677.

1-(Benzothiazol-2-yl)-4-(4-chlorophenyl)-6-hydroxy-2-oxo-1,2dihydropyridine-3,5-dicarbonitrile (11c). Creamy white crystals, yield: $1.78 \mathrm{~g}(88 \%), \mathrm{mp}$ above $300{ }^{\circ} \mathrm{C}$; IR $(\mathrm{KBr}): \nu / \mathrm{cm}^{-1} 3180$ $(\mathrm{OH}), 2221(\mathrm{CN}), 1673(\mathrm{CO}) ;{ }^{1} \mathrm{H}$ NMR (DMSO- $\left.d_{6}\right): \delta=7.43(\mathrm{~d}, J=$ $8.4 \mathrm{~Hz}, 2 \mathrm{H}, \mathrm{Ar}-\mathrm{H}), 7.49-7.55$ (m, 2H, Ar-H), 7.59 (d, $J=8.4 \mathrm{~Hz}$, $2 \mathrm{H}, \mathrm{Ar}-\mathrm{H}), 8.08(\mathrm{~d}, J=8.2 \mathrm{~Hz}, 1 \mathrm{H}, \mathrm{Ar}-\mathrm{H}), 8.58(\mathrm{~d}, J=8.2 \mathrm{~Hz}, 1 \mathrm{H}$, $\mathrm{Ar}-\mathrm{H}$ ) and $13.31 \mathrm{ppm}(\mathrm{s}, 1 \mathrm{H}, \mathrm{OH}) ;{ }^{13} \mathrm{C}$ NMR (DMSO- $\left.d_{6}\right): \delta=$ 98.11 (C5), 102.83 (C3), 115.13 (CN), 118.63, 123.32, 123.34, 127.11, 127.52, 128.18, 129.08, 133.52, 135.44, 135.72, 154.32, 156.65, 160.06, 162.34 and $166.07 \mathrm{ppm}$ (Ar-C and CO); MS (EI): $m / z(\%) 406\left(\mathrm{M}^{+}+2,40.02\right), 405\left(\mathrm{M}^{+}+1,46.11\right), 404\left(\mathrm{M}^{+}, 100\right)$; HRMS (EI): $m / z$ calcd for $\mathrm{C}_{20} \mathrm{H}_{9} \mathrm{ClN}_{4} \mathrm{O}_{2} \mathrm{~S}\left(\mathrm{M}^{+}\right)$404.0129, found 404.0129.

$\mathrm{N}$-(Benzothiazol-2-yl)-2-oxo-6-phenyl-1,2-dihydropyridine-3carboxamide (17). A solution of cyanoacetamide 4 a (1.09 g, 5 $\mathrm{mmol})$ and enaminone 13 (0.9 g, $5 \mathrm{mmol})$ in $\mathrm{AcOH}(15 \mathrm{~mL})$ containing anhydrous sodium acetate $(1.0 \mathrm{~g})$ was sonicated in an MKC6, Guyson ultrasonic bath (Model-MKC6, operating frequency $38 \mathrm{kHz} \pm 10 \%$ and output power of $110 \mathrm{~W}$ ) for 40 minutes at $80{ }^{\circ} \mathrm{C}$. The reaction was monitored by TLC and continued until the starting substrates were completely consumed, then left to cool to room temperature. The solid product formed after cooling to room temperature was separated by filtration, washed with ethanol, dried and recrystallized from an ethanol/dioxane $(1: 2)$ mixture, to give 17 as orange crystals, yield: $1.35 \mathrm{~g}$ (78\%), mp above $300{ }^{\circ} \mathrm{C}$; IR (KBr): $\nu / \mathrm{cm}^{-1}$ 3335, 3284 (2NH), 1681, 1654 (2CO); ${ }^{1} \mathrm{H}$ NMR (DMSO- $\left.d_{6}\right): \delta=$ $6.98(\mathrm{~d}, J=7.2 \mathrm{~Hz}, 1 \mathrm{H}, \mathrm{H}-5), 7.31$ (t, $J=7.2 \mathrm{~Hz}, 1 \mathrm{H}, \mathrm{Ar}-\mathrm{H}), 7.44$ $(\mathrm{t}, J=7.2 \mathrm{~Hz}, 1 \mathrm{H}, \mathrm{Ar}-\mathrm{H}), 7.54-7.6(\mathrm{~m}, 3 \mathrm{H}, \mathrm{Ar}-\mathrm{H}), 7.77(\mathrm{~d}, J=$ $7.8 \mathrm{~Hz}, 1 \mathrm{H}, \mathrm{Ar}-\mathrm{H}), 7.85$ (d, $J=8.0 \mathrm{~Hz}, 2 \mathrm{H}, \mathrm{Ar}-\mathrm{H}), 7.99$ (d, $J=$ $7.8 \mathrm{~Hz}, 1 \mathrm{H}, \mathrm{Ar}-\mathrm{H}), 8.54$ (d, J= 7.2 Hz, 1H, H-4), $13.22(\mathrm{~s}, 1 \mathrm{H}, \mathrm{NH})$ and $13.59 \mathrm{ppm}(\mathrm{s}, 1 \mathrm{H}, \mathrm{NH}) ;{ }^{13} \mathrm{C}$ NMR (DMSO- $\left.d_{6}\right): \delta=106.32$, 115.48 (CN), 120.71, 121.81, 123.74, 126.26, 127.79, 129.04, 131.32, 131.74, 131.85, 145.47, 148.69, 152.49, 157.05, 162.15 and $163.54 \mathrm{ppm}$ (Ar-C and CO); MS (EI): $m / z(\%) 348\left(\mathrm{M}^{+}+1\right.$, 9.12), $347\left(\mathrm{M}^{+}, 38.79\right)$, HRMS (EI): $m / z$ calcd for $\mathrm{C}_{19} \mathrm{H}_{13} \mathrm{~N}_{3} \mathrm{O}_{2} \mathrm{~S}$ $\left(\mathrm{M}^{+}\right)$347.0723, found 347.0724 .

\section{Conflicts of interest}

The authors declare that they have no competing interests.

\section{Acknowledgements}

The facilities of Analab/SAF by the University of Kuwait through research grants GS01/01, GS01/05, GS01/03, and GS03/08 are gratefully acknowledged.

\section{References}

1 M. Sainsbury, Heterocyclic chemistry, Royal Society of Chemistry, Cambridge 2001.

2 T. Taniguchi and K. A. Ogasawara, Org. Lett., 2000, 2, 31933195.

3 G. D. Henry, Tetrahedron, 2004, 60, 6043-6061.

4 I. Gomez, E. Alonso, D. J. Ramon and M. Yus, Tetrahedron, 2000, 56, 4043-4052.

5 A. Carreno, C. Zuniga, D. Paez-Hernandez, M. Gacitua, R. Polanco, C. Otero, R. Arratia-Perez and J. A. Fuentes, New J. Chem., 2018, 42, 8851-8863.

6 K. R. Amperayani, K. N. Kumar and U. D. Parimi, Res. Chem. Intermed., 2018, 44, 3549-3564.

7 M. Vrabel, M. Hocek, L. Havran, M. Fojta, I. Votruba, B. Klepetařova, R. Pohl, L. Rulišek, L. Zendlova, P. Hobza, I. H. Shih, E. Mabery and R. Mackman, Eur. J. Inorg. Chem., 2007, 2007, 1752-1769.

$8 \mathrm{~J}$. Fu, S. Karur and K. B. Pfister, PCT Int. Appl., WO 2018073753 A1 20180426, 2018.

9 A. Worachartcheewan, S. Prachayasittikul, R. Pingaew, C. Nantasenamat, T. Tantimongcolwat, S. Ruchirawat and V. Prachayasittikul, Med. Chem. Res., 2012, 21, 3514-3522.

10 S. Riaz, I. U. Khan, M. Bajda, M. Ashraf, Q. Ain, A. Shaukat, T. Ur Rehman, S. Mutahir, S. Hussain, G. Mustafa and M. Yar, Bioorg. Chem., 2015, 63, 64-71.

11 J. Easmon, G. Pürstinger, K.-S. Thies, G. Heinisch and J. Hofmann, Med. Chem., 2006, 49(21), 6343-6350.

12 G. S. Kumar, Y. Poornachandra, S. K. Gunda, K. R. Reddy, J. Mohmed, K. Shaik, C. G. Kumar and B. Narsaiah, Bioorg. Med. Chem. Lett., 2018, 28, 2328-2337.

13 M. Wei, X. Peng, L. Xing, Y. Dai, R. Huang, M. Geng, A. Zhang, J. Ai and Z. Song, Eur. J. Med. Chem., 2018, 154, 9-28.

14 M. P. Savic, J. J. Ajdukovic, J. J. Plavsa, S. S. Bekic, A. S. Celic, O. R. Klisuric, D. S. Jakimov, E. T. Petri and E. A. Djurendic, Med. Chem. Commun., 2018, 9, 969-981.

15 J. Liu, Z. Wang, A. Levin, T. J. Emge, P. R. Rablen, D. M. Floyd and S. Knapp, J. Org. Chem., 2014, 79, 7593-7599.

16 T. M. Chapman, S. A. Osborne, C. Wallace, K. Birchall, N. Bouloc, H. M. Jones, K. H. Ansell, D. L. Taylor, B. Clough, J. L. Green and A. A. Holder, J. Med. Chem., 2014, 57, 3570-3587.

17 N. S. Gray, T. Zhang, J. Hatcher and S. J. Buhrlage, PCT Int. Appl., WO 2018098367 A1 20180531, 2018.

18 S. K. Nechipadappu and D. R. Trivedi, J. Mol. Struct., 2017, 1141, 64-74.

19 N. Bharti, M. R. Maurya, F. Naqvi and A. Azam, Bioorg. Med. Chem. Lett., 2000, 10, 2243-2245.

20 S. M. Sondhi, M. Dinodia and A. Kumar, Bioorg. Med. Chem., 2006, 14, 4657-4663.

21 M. Lopez-Martinez, H. Salgado-Zamora, E. R. San-Juan, S. Zamudio, O. Picazo, M. E. Campos and E. B. NaranjoRodriguez, Drug Dev. Res., 2010, 71, 371-381.

22 T. B. Chaston and D. R. Richardson, J. Biol. Inorg Chem., 2003, 8, 427-438. 
23 A. Kamal, M. A. Syed and S. M. Mohammed, Expert Opin. Ther. Pat., 2015, 25, 335-349.

24 R. S. Keri, M. R. Patil, S. A. Patil and S. Budagumpi, Eur. J. Med. Chem., 2015, 89, 207-251.

25 L. L. Bozec and C. J. Moody, Aust. J. Chem., 2009, 62, 639-647. 26 C. Palomo, M. Oiarbide and A. Mielgo, Angew. Chem., Int. Ed., 2004, 43, 5442-5444.

27 S. Letort, M. Lejeune, N. Kardos, E. Métay, F. Popowycz, M. Lemaire and M. Draye, Green Chem., 2017, 19, 4583-4590.

28 B. Banerjee, Ultrason. Sonochem., 2017, 35, 15-35.

29 L.-C. Campeau and K. Fagnou, Org. Synth., 2011, 88, 22-32. 30 J. Z. Deng, D. V. Paone, A. T. Ginnetti, H. Kurihara, S. D. Dreher, S. A. Weissman, S. R. Stauffer and C. S. Burgey, Org. Lett., 2009, 11, 345-347.

31 M. R. Luzung, J. S. Patel and J. Yin, J. Org. Chem., 2010, 75, 8330-8332.

32 J. R. Manning and H. M. L. Manning, J. Am. Chem. Soc., 2008, 130, 8602-8603.

33 T. J. Donohoe, J. A. Basutto, J. F. Bower and A. Rathi, Org. Lett., 2011, 13, 1036-1039.

34 H. M. Ibrahim and H. Behbehani, Molecules, 2014, 19, 26372654.

35 H. Behbehani, H. M. Ibrahim and M. H. Elnagdi, Tetrahedron, 2013, 69, 6176-6184.

36 H. Behbehani and H. M. Ibrahim, Tetrahedron, 2013, 69, 10535-10543.

37 H. M. Ibrahim, H. Behbehani and M. H. Elnagdi, Chem. Cent. J., 2013, 7, 123.

38 B. Banerjee, Ultrason. Sonochem., 2017, 35, 1-14; H. Behbehani, H. M. Ibrahim and K. M. Dawood, RSC Adv., 2015, 5, 25642-25649.

39 L. S. da Silveira Pinto and M. V. N. de Souza, Synthesis, 2017, 49, 2555-2561.

40 D. Bandyopadhyay, S. Mukherjee, L. C. Turrubiartes and B. K. Banik, Tetrahedron, 2012, 19, 969-973; H. Behbehani and H. M. Ibrahim, RSC Adv., 2016, 6, 52700-52709.

41 L. Pizzuti, L. A. Piovesan, A. F. C. Flores, F. H. Quina and C. M. P. Pereira, Ultrason. Sonochem., 2009, 16, 728-731; W. A. A. Arafa and H. M. Ibrahim, RSC Adv., 2018, 8, 10516-10521.

42 M. Vidal, M. García-Arriagada, M. C. Rezende and M. Domínguez, Synthesis, 2016, 48, 4246-4252.

43 L. Pizzuti, P. L. G. Martins, B. A. Ribeiro, F. H. Quina, E. Pinto, A. F. C. Flores, D. Venzke and C. M. P. Pereira, Ultrason. Sonochem., 2010, 17, 34-37.
44 H. Behbehani, H. M. Ibrahim, S. Makhseed, M. H. Elnagdi and H. Mahmoud, Eur. J. Med. Chem., 2012, 52, 61-65; A. Ueda, T. Umeno, M. Doi, K. Akagawa, K. Kudo and M. Tanaka, J. Org. Chem., 2016, 81, 6343-6356; S. Kim, S. Kang, G. Kim and Y. Lee, J. Org. Chem., 2016, 81, 40484057; A. M. Farag, N. A. Kheder and K. M. Dawood, Int. J. Mod. Org. Chem., 2013, 2, 26-39; I. V. Dyachenko, V. D. Dyachenko and E. B. Rusanov, Russ. J. Org. Chem., 2007, 43, 83-89; S. Bondock, W. Fadaly and M. A. Metwally, Eur. J. Med. Chem., 2010, 45, 3692-3701.

45 L. Wu, R. Jin, L. Li, X. Hu, T. Cheng and G. Liu, Org. Lett., 2017, 19, 3047-3050; A. B. Smith III, O. Atasoylu and D. C. Beshore, Synlett, 2009, 16, 2643-2646; M. Fernández, U. Uria, L. Orbe, J. L. Vicario, E. Reyes and L. Carrillo, J. Org. Chem., 2014, 79, 230-239.

46 Y. N. Mabkhot, N. A. Kheder and A. M. Farag, Heterocycles, 2010, 81, 2369-2376; R. E. Khidre, I. A. M. Radini and D. A. Ibrahim, ARKIVOC, 2016, 5, 301-317; M. A. Raslan, S. M. Sayed and M. A. Khalil, J. Heterocycl. Chem., 2016, 53, 727-733.

47 J. Stetinova, R. Kada, J. Lesko, L. Zalibera, D. Il avsky and A. Bartovic, Collect. Czech. Chem. Commun., 1995, 60, 9991008.

48 A. Chanda and V. V. Fokin, Chem. Rev., 2009, 109, 725-748. 49 C. Capello, U. Fischer and K. Hungerbühler, Green Chem., 2007, 9, 927-934.

50 G. M. Sheldrick, Acta Crystallogr., 2008, A64, 112-122.

$51 \mathrm{H}$. M. Ibrahim, S. Makhseed, R. M. Abdel-Motaleb, A. A. Makhlouf and M. H. Elnagdi, Heterocycles, 2007, 71, 1951-1966.

52 Crystallographic data for 7a (ref. CCDC 1858431) can be obtained on request from the director, Cambridge Crystallographic Data Center, 12 Union Road, Cambridge CB2 1EW, UK.

53 Crystallographic data for $7 \mathbf{b}$ (ref. CCDC 1858432) can be obtained on request from the director, Cambridge Crystallographic Data Center, 12 Union Road, Cambridge CB2 1EW, UK.

54 Crystallographic data for 7d (ref. CCDC 1858433) can be obtained on request from the director, Cambridge Crystallographic Data Center, 12 Union Road, Cambridge CB2 1EW, UK.

55 Crystallographic data for $7 \mathbf{i}$ (ref. CCDC 1858434) can be obtained on request from the director, Cambridge Crystallographic Data Center, 12 Union Road, Cambridge CB2 1EW, UK. 